\title{
Geology and Assessment of Undiscovered Oil and Gas Resources of the Timan-Pechora Basin Province, Russia, 2008
}

Chapter $\mathrm{N}$ of

The 2008 Circum-Arctic Resource Appraisal

Professional Paper 1824

U.S. Department of the Interior

U.S. Geological Survey 
Cover. Eocene strata along the north side of Van Keulenfjorden, Svalbard, include basin-floor fan, marine slope, and deltaic to fluvial depositional facies. The age and facies of these strata are similar to Tertiary strata beneath the continental shelves of Arctic Eurasia, thus providing an analog for evaluating elements of those petroleum systems. Relief from sea level to top of upper bluff is approximately 1,500 feet. Photograph by David Houseknecht. 


\section{Geology and Assessment of Undiscovered Oil and Gas Resources of the Timan-Pechora Basin Province, Russia, 2008}

By Christopher J. Schenk

Chapter $\mathrm{N}$ of

The $\mathbf{2 0 0 8}$ Circum-Arctic Resource Appraisal

Edited by T.E. Moore and D.L. Gautier

Professional Paper 1824 


\title{
U.S. Department of the Interior RYAN K. ZINKE, Secretary
}

\section{U.S. Geological Survey William H. Werkheiser, Acting Director}

\author{
U.S. Geological Survey, Reston, Virginia: 2017
}

For more information on the USGS — the Federal source for science about the Earth, its natural and living resources, natural hazards, and the environment-visit https://www.usgs.gov or call 1-888-ASK-USGS.

For an overview of USGS information products, including maps, imagery, and publications, visit https://store.usgs.gov.

Any use of trade, firm, or product names is for descriptive purposes only and does not imply endorsement by the U.S. Government.

Although this information product, for the most part, is in the public domain, it also may contain copyrighted materials as noted in the text. Permission to reproduce copyrighted items must be secured from the copyright owner.

Suggested citation:

Schenk, C.J., 2017, Geology and assessment of undiscovered oil and gas resources of the Timan-Pechora Basin Province, Russia, 2008, chap. N of Moore, T.E., and Gautier, D.L., eds., The 2008 Circum-Arctic Resource Appraisal: U.S. Geological Survey Professional Paper 1824, 22 p., https://doi.org/10.3133/pp1824N.

ISSN 2330-7102 (online) 


\section{The 2008 Circum-Arctic Resource Appraisal}

\section{Chapters}

A. Introduction to the 2008 Circum-Arctic Resource Appraisal (CARA) Professional Paper By Donald L. Gautier and Thomas E. Moore

B. Methodology for Assessment of Undiscovered Oil and Gas Resources for the 2008 Circum-Arctic Resource Appraisal

By Ronald R. Charpentier

\section{North America}

C. Geology and Assessment of Undiscovered Oil and Gas Resources of the Chukchi Borderland Province, 2008

By Kenneth J. Bird and David W. Houseknecht

D. Geology and Assessment of Undiscovered Oil and Gas Resources of the Hope Basin

Province, 2008

By Kenneth J. Bird, David W. Houseknecht, and Janet K. Pitman

E. Geology and Assessment of Undiscovered Oil and Gas Resources of the Arctic Alaska Petroleum Province, 2008

By David W. Houseknecht, Kenneth J. Bird, and Christopher P. Garrity

F. Geology and Assessment of Undiscovered Oil and Gas Resources of the Yukon Flats Basin Province, 2008

By Kenneth J. Bird and Richard G. Stanley

G. Geology and Assessment of Undiscovered Oil and Gas Resources of the Northwest Canada Interior Basins Province, Arctic Canada, 2008

By Marilyn E. Tennyson and Janet K. Pitman

H. Geology and Assessment of Undiscovered Oil and Gas Resources of the Franklinian Shelf Province, Arctic Canada and North Greenland, 2008

By Marilyn E. Tennyson and Janet K. Pitman

I. Geology and Assessment of Undiscovered Oil and Gas Resources of the Sverdrup Basin Province, Arctic Canada, 2008

By Marilyn E. Tennyson and Janet K. Pitman

\section{Greenland}

J. Geology and Assessment of Undiscovered Oil and Gas Resources of the West GreenlandEast Canada Province, 2008

By Christopher J. Schenk 
K. Geology and Assessment of Undiscovered Oil and Gas Resources of the East Greenland Rift Basins Province, 2008

By Donald L. Gautier

\section{North Atlantic Ocean}

L. Geology and Assessment of Undiscovered Oil and Gas Resources of the Jan Mayen Microcontinent Province, 2008

By Thomas E. Moore and Janet K. Pitman

\section{Eurasia}

M. Geology and Assessment of Undiscovered Oil and Gas Resources of the Mezen' Basin Province, 2008

By Timothy R. Klett and Janet K. Pitman

N. Geology and Assessment of Undiscovered Oil and Gas Resources of the Timan-Pechora Basin Province, Russia, 2008

By Christopher J. Schenk

0. Geology and Assessment of Undiscovered Oil and Gas Resources of the East Barents Basins Province and the Novaya Zemlya Basins and Admiralty Arch Province

By Timothy R. Klett

P. Geology and Assessment of Undiscovered Oil and Gas Resources of the North Kara Basins and Platforms Province, 2008

By Timothy R. Klett and Janet K. Pitman

0. Geology and Assessment of Undiscovered Oil and Gas Resources of the Northern West Siberian Mesozoic Composite Total Petroleum System of the West Siberian Basin Province, Russia, 2008

By Christopher J. Schenk

R. Geology and Assessment of Undiscovered Oil and Gas Resources of the Yenisey-Khatanga Basin Province, 2008

By Timothy R. Klett and Janet K. Pitman

S. Geology and Assessment of Undiscovered Oil and Gas Resources of the Northwest Laptev Sea Shelf Province, 2008

By Timothy R. Klett and Janet K. Pitman

T. Geology and Assessment of Undiscovered Oil and Gas Resources of the Lena-Anabar Basin Province, 2008

By Timothy R. Klett and Janet K. Pitman 
U. Geology and Assessment of Undiscovered Oil and Gas Resources of the Tunguska Basin Province, 2008

By Christopher J. Wandrey and Timothy R. Klett

V. Geology and Assessment of Undiscovered Oil and Gas Resources of the Lena-Vilyui Basin Province, 2008

By Timothy R. Klett and Janet K. Pitman

W. Geology and Assessment of Undiscovered Oil and Gas Resources of the Laptev Sea Shelf Province, 2008

By Timothy R. Klett and Janet K. Pitman

X. Geology and Assessment of Undiscovered Oil and Gas Resources of the Zyryanka Basin Province, 2008

By Timothy R. Klett and Janet K. Pitman

Y. Geology and Assessment of Undiscovered Oil and Gas Resources of the East Siberian Sea Basin Province, 2008

By Kenneth J. Bird, David W. Houseknecht, and Janet K. Pitman

Z. Geology and Assessment of Undiscovered Oil and Gas Resources of the Vilkitskii Basin Province, 2008

By Kenneth J. Bird, David W. Houseknecht, and Janet K. Pitman

AA. Geology and Assessment of Undiscovered Oil and Gas Resources of the Long Strait Province, Russian High Arctic, 2008

By Kenneth J. Bird, David W. Houseknecht, and Janet K. Pitman

\section{Arctic Ocean}

BB. Geology and Assessment of Undiscovered Oil and Gas Resources of the Amerasia Basin Petroleum Province, 2008

By David W. Houseknecht, Kenneth J. Bird, and Christopher P. Garrity

CC. Geology and Assessment of Undiscovered Oil and Gas Resources of the LomonosovMakarov Province, Central Arctic Ocean, 2008

By Thomas E. Moore, Kenneth J. Bird, and Janet K. Pitman

DD. Geology and Assessment of Undiscovered Oil and Gas Resources of the Eurasia Basin Province, Eastern Arctic Ocean, 2008

By Thomas E. Moore and Janet K. Pitman 


\section{Contents}

The 2008 Circum-Arctic Resource Appraisal .................................................................................ii

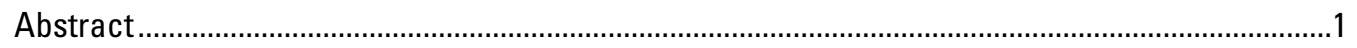

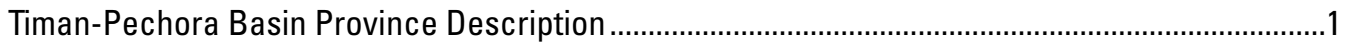

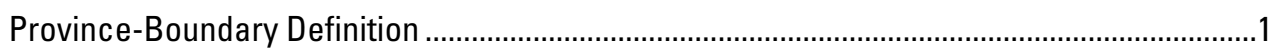

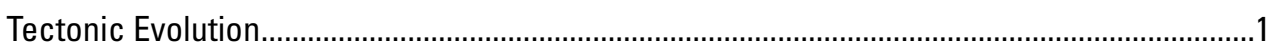

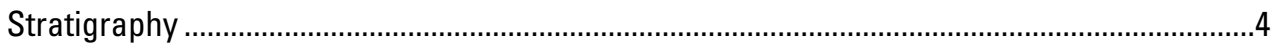

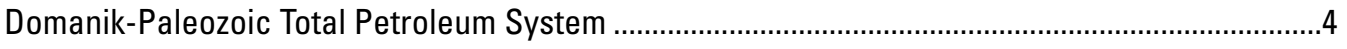

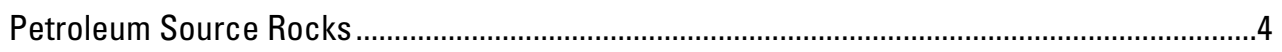

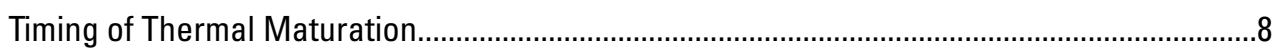

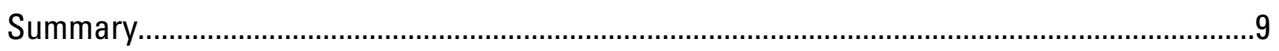

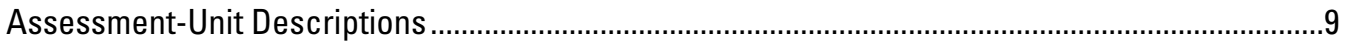

Northwest Izhma Depression Assessment Unit.....................................................................

Geologic Model for Assessment .............................................................................

Geologic Analysis of Assessment Unit Probability …………...........................................10

Main Basin Platform Assessment Unit .............................................................................

Geologic Model for Assessment...........................................................................10

Geologic Analysis of Assessment-Unit Probability.....................................................10

Estimation of the Sizes and Numbers of Undiscovered Oil and Gas Fields .....................13

Coproduct Ratios and Ancillary Data .........................................................................14

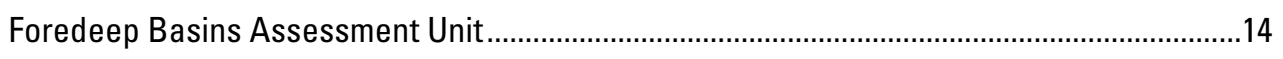

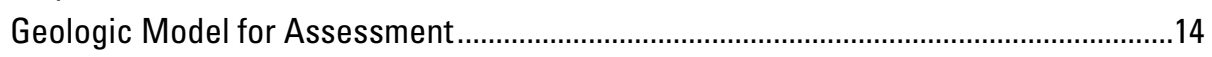

Geologic Analysis of Assessment Unit Probability .....................................................14

Estimation of the Sizes and Numbers of Undiscovered Oil and Gas Fields ....................15

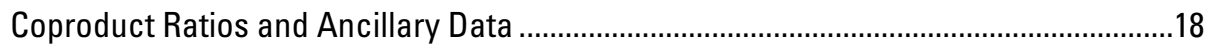

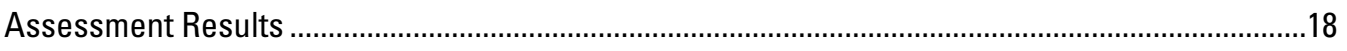

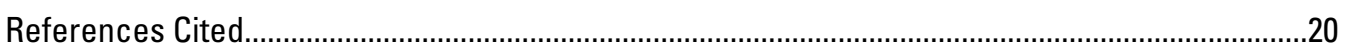

\section{Appendixes}

[Available for download at https://doi.org/10.3133/pp1824N]

1. Input Data for the Northwest Izhma Depression Assessment Unit

2. Basin Evolution Chart for the Main Basin Platform Assessment Unit

3. Input Data for the Main Basin Platform Assessment Unit

4. Basin Evolution Chart for the Foredeep Basins Assessment Unit

5. Input data for the Foredeep Basins Assessment Unit

6. Detailed Assessment Results for the Main Basin Platform Assessment Unit

7. Detailed Assessment Results for the Foredeep Basins Assessment Unit 


\section{Figures}

1. Map showing location of the Timan-Pechora Basin Province, Russia .............................2

2. Chart showing geologic events in and tectonic evolution of the Timan-Pechora Basin

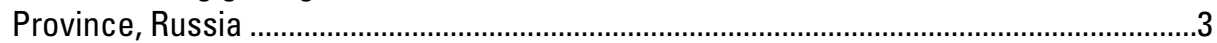

3. Regional cross section of the Timan-Pechora Basin Province, Russia ..............................5

4. Stratigraphic column for the Timan-Pechora Basin Province, Russia ..............................6

5. Total Petroleum System map (TPS) of the Timan-Pechora Basin Province, Russia ........7

6. Geologic cross section for undiscovered petroleum accumulations in the Main Basin Platform Assessment Unit, Timan-Pechora Basin Province, Russia ...............................11

7. Burial-history diagram for the Main Basin Platform Assessment Unit, based on stratigraphic data from the Vozey-51 well...............................................................12

8. Chart of Total Petroleum System events in the Main Basin Platform Assessment Unit, Timan-Pechora Basin Province, Russia.....................................................................13

9. Graphs showing grown sizes and numbers of oil and gas fields in the Main Basin Platform Assessment Unit, Timan-Pechora Basin Province, Russia ...............................14

10. Geologic cross section for undiscovered petroleum accumulations in the Foredeep Basins Assessment Unit, Timan-Pechora Basin Province, Russia ..................................15

11. Burial-history diagram for the Foredeep Basins Assessment Unit, Timan-Pechora Basin Province, Russia

12. Chart of total-petroleum-system events in the Foredeep Basins Assessment Unit, Timan-Pechora Basin Province, Russia.

13. Grown sizes and numbers of gas fields in the Foredeep Basins Assessment Unit, Timan-Pechora Basin Province, Russia.

\section{Table}

1. Assessment results (conventional undiscovered resources) for the Timan-Pechora Province 



\title{
Chapter N
}

\section{Geology and Assessment of Undiscovered Oil and Gas Resources of the Timan-Pechora Basin Province, Russia, 2008}

\author{
By Christopher J. Schenk
}

\section{Abstract}

The Timan-Pechora Basin Province is a triangular area that represents the northeasternmost cratonic block of east European Russia. A 75-year history of petroleum exploration and production in the area there has led to the discovery of more than 16 billion barrels of oil (BBO) and 40 trillion cubic feet of gas (TCFG). Three geologic assessment units (AUs) were defined for assessing the potential for undiscovered oil and gas resources in the province: (1) the Northwest Izhma Depression AU, which includes all potential structures and reservoirs that formed in the northwestern part of the IzhmaPechora Depression, although this part of the basin contains only sparse source and reservoir rocks and so was not assessed quantitatively; (2) the Main Basin Platform AU, which includes all potential structures and reservoirs that formed in the central part of the basin, where the tectonic and petroleum system evolution was complex; and (3) the Foredeep Basins $\mathrm{AU}$, which includes all potential structures and reservoirs that formed within the thick sedimentary section of the foredeep basins west of the Uralian fold and thrust belt during the Permian and Triassic Uralian orogeny.

For the Timan-Pechora Basin Province, the estimated means of undiscovered resources are 3.3 BBO, 17 TCFG, and 0.3 billion barrels of natural-gas liquids (BBNGL). For the AU areas north of the Arctic Circle in the province, the estimated means of undiscovered resources are 1.7 BBO, 9.0 TCFG, and 0.2 BBNGL. These assessment results indicate that exploration in the Timan-Pechora Basin Province is at a mature level.

\section{Timan-Pechora Basin Province Description}

\section{Province-Boundary Definition}

The Timan-Pechora Basin Province as defined in this study is a triangular area of $379,000 \mathrm{~km}^{2}$ that represents the northeasternmost cratonic block of east European Russia (fig. 1). The southwest boundary of the province is the Timan Ridge, a northwest-trending geologic feature of positive relief with a long history of tectonic activity beginning in the Precambrian (Malyshev and others, 1991); its southeast boundary is the Ural Mountains, a westward-verging Permian and Triassic fold and thrust belt that intersects the Timan Ridge to the south; its northeast boundary is the Pay-Khoy Ridge and the Novaya Zemlya fold belt; and its north boundary is coincident with the southern boundary of the Kolguyev Terrace AU of the South Barents Sea Province (T.R. Klett, oral commun., 2008). The Timan-Pechora Basin Province extends southward of the Arctic Circle (fig. 1).

Though historically called the Timan-Pechora Basin, the province comprises a series of structural highs and lows with a complex Paleozoic and Mesozoic structural and tectonic evolution (Otto and Bailey, 1995). One of the most striking geologic aspects of the Timan-Pechora Basin Province is the dominant northwest-southeast structural grain outlined by these structural highs and lows (fig. 1). Much of the literature on the province relates to the origin and evolution of its various structural highs (or swells, uplifts) and structural lows (or depressions, troughs).

The Timan-Pechora Basin Province has a long history of oil and gas exploration and production (Sagers, 1994). The first field was discovered in 1930, and since then more than 230 fields have been discovered, and more than 5,400 wells have been drilled. Several previous studies (Ulmishek, 1982; Lindquist, 1999; Fossum and others, 2001) have summarized the potential oil and gas resources remaining in the province after the more than 75 years of exploration.

\section{Tectonic Evolution}

The tectonic evolution of the Timan-Pechora Basin Province (fig. 2) has been a subject of research since the 1970s. Two of the first compilations of the petroleum geology of the province (in English) were by Meyerhoff (1980) and Ulmishek (1982), who summarized much of the extensive Russian research. As defined, the Timan-Pechora Basin Province is a complex amalgamation of rift basins, inverted rifts, and horsts; 


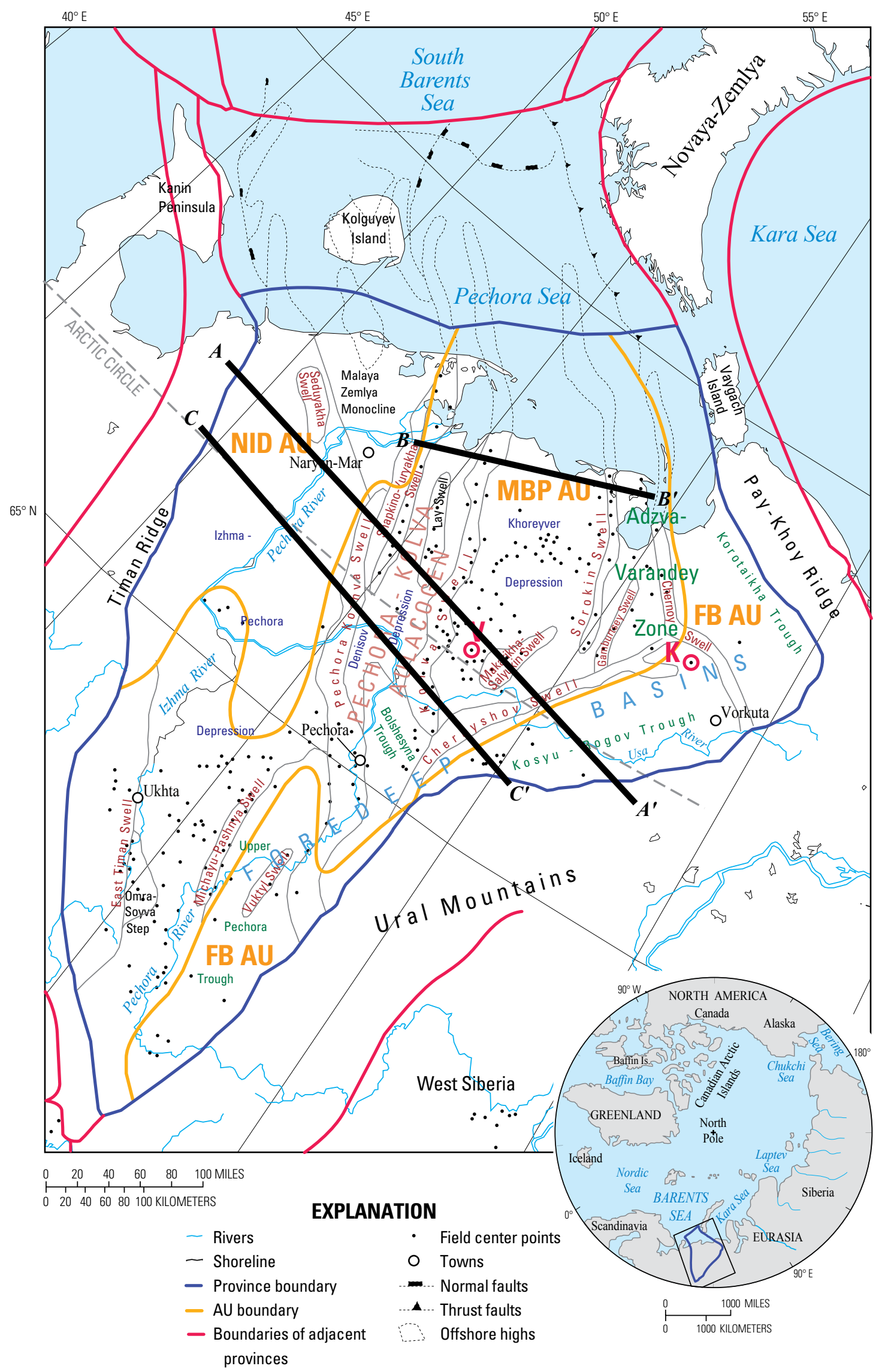

Figure 1. Map showing location of the Timan-Pechora Basin Province, Russia. Total Petroleum System (TPS) and province boundaries coincide. Three assessment units (AUs) are defined in this study. NID AU is the Northwest Izhma Depression AU; MBP AU is the Main Basin Platform AU; and FB AU is the Foredeep Basins AU. Note that the AUs each extend southward of the Arctic Circle. K, Korotaikha-1 well; V, Vozey-51 well. 
a series of foreland basins also formed along the Uralian orogenic front on the southeastern margin of the province. All these structures follow a Neoproterozoic structural grain (Artyushkov and Baer, 1986) to constitute a Paleozoic structural entity (Stephenson and others, 2006). By the Neoproterozoic, several crustal blocks accreted to the margin of the East European craton to form the basement of what is now the Timan-Pechora Basin. These blocks have a diverse lithology and provenance, with various degrees of metamorphism and intrusion by granitoids. The boundaries between blocks are marked by sutures (Kouznetsov and others, 2005). Accretion was followed in the Early Cambrian by uplift and erosion (Ulmishek, 1982; Clarke, 1994) on a rift shoulder as continental crust attenuated before the opening of the Uralian Ocean between the East European and Siberian cratonic blocks.

Rifting was most pronounced during the Ordovician and Silurian (O'Leary and others, 2004), and it occurred in two phases that involved attenuation of continental crust as Siberia was rifted from East Europe along northwest-trending faults that reflected the Neoproterozoic structural grain. Some of the rift basins are extensive and have been the focus of numerous investigations because of their oil and gas potential. Rifting was followed by a period of thermal relaxation and sag, with the formation of a passive margin. During this time, at least two possible petroleum source rocks were deposited across large parts of the Timan-Pechora Basin.

Passive-margin sedimentation in the early Paleozoic was manifested mainly by the formation of extensive carbonate platforms and marginal reefs, as well as periplatform basins, with deep-water sedimentation of organic-bearing strata. By the beginning of the Devonian, the Uralian Ocean basin had formed by sea-floor spreading, and passive-margin sedimentation and progradation continued along the eastern margin of the Timan-Pechora Basin. The Middle Devonian was also a time of widespread thermal relaxation and sag-related sedimentation.

Rifting continued throughout the Middle and Late Devonian in the Timan-Pechora Basin (O'Leary and others, 2004), in association with basaltic magmatism similar to that in the South Barents Sea Province to the north (fig. 1). Rifting was once again followed by thermal relaxation and sag-related sedimentation, which included the deposition of the Upper Devonian Domanik Formation, one of the most important petroleum-source rocks in the province. Organic-rich Domanik sediment was deposited in deep water in a backarc setting outboard of successive carbonate platforms. Carbonate-platform sedimentation continued throughout the Devonian into the Carboniferous.

The causal mechanism of the Devonian phase of rifting was ascribed to backarc extension by O'Leary and others (2004). Their interpretation suggests that during this time (1) the Uralian Ocean began to close, leading to the formation of a volcanic arc east of the Timan-Pechora Basin, concomitant with westward-dipping subduction as Siberia moved closer to the margin; and (2) phases of compression also occurred as the structural regime in the backarc setting alternated between

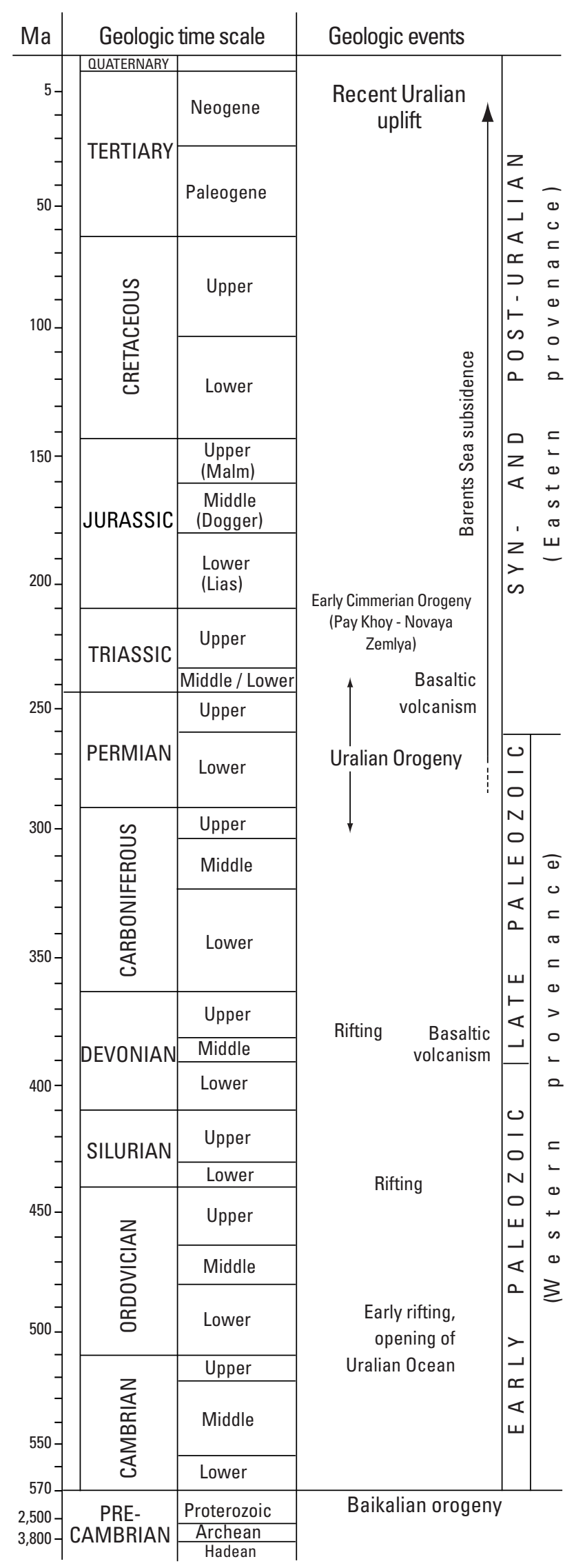

Figure 2. Chart showing geologic events in and tectonic evolution of the Timan-Pechora Basin Province (modified from Lindquist, 1999), Russia. See figure 1 for location. 
extension and compression, which served to invert some of the older extensional rift structures in the basin.

The structural setting of the Timan-Pechora Basin changed radically in the early Carboniferous. Westwarddirected compression associated with closing of the Uralian Ocean resulted in widespread inversion of structures as the Uralian orogeny impinged from the east, a prelude to the formation of an extensive foreland basin in the eastern part of the basin. Clastic deposition occurred during the Carboniferous along with carbonate sedimentation.

During the Permian and Triassic, the Uralian Ocean closed, and the westward-verging Uralian fold and thrust belt formed, along with several foreland basins, such as the KosyuRogov Trough in the eastern part of the Timan-Pechora Basin. The foreland basins formed as thrust loading caused crustal flexure and the creation of several kilometers of accommodation space for siliciclastic deposition in the foredeep. As much as $12 \mathrm{~km}$ of deposition has been documented during this time of foreland evolution. O'Leary and others (2004) concluded that during this time of intense compression in the Permian and Triassic, several phases of rifting occurred, despite being within the Uralian compressional regime. They attributed the rifting to large-scale convection in the mantle, resulting in tensional stresses in the backarc setting.

A minor phase of compression in the northeastern part of the Timan-Pechora Basin occurred during the Late Triassic and Early Jurassic. This event is related to the formation of the Pay-Khoy Ridge and the Novaya Zemlya fold belt (fig. 1) during the Cimmerian orogeny (Lindquist, 1999).

The Timan-Pechora Basin Province is made up of several broadly defined structural domains related to the tectonic events described above (fig. 3). The eastern part of the province contains several foreland basins arranged in echelon along the Uralian orogenic front that define the area of the Foredeep Basins AU; the central part of the province defines the Main Basin Platform AU, which includes most of the inverted rift structures; and the Northwest Izhma Depression AU is basically defined as the area in which few petroleumsource rocks are present, owing to widespread erosion (fig.1).

\section{Stratigraphy}

The stratigraphy of the Timan-Pechora Basin Province reflects the tectonic and sedimentary history of the eastern margin of the East European craton (fig. 4). Cambrian rocks are missing because of rift-shoulder erosion associated with crustal extension that preceded the opening of the proto-Uralian Ocean. Rifting during the Ordovician and Silurian resulted in deep rift basins that eventually filled with classic synrift facies, and the overall formation of a passive margin from the Ordovician through Early Devonian is characterized by widespread carbonate platforms and deep-basin environments where organic-rich shales were deposited. The Middle Devonian is characterized by siliciclastic deposits, which gradually changed to carbonate platform and basin sediment in the Upper Devonian and Carboniferous. The early Permian began with carbonate deposition that changed to siliciclastic sediment in the adjacent foreland basin to the west of the Uralian fold and thrust belt. Siliciclastic sedimentation continued into the Triassic and Jurassic. Dedeev and others (1994) identified three depositional megacycles in the Timan-Pechora Basin: (1) Cambrian through Early Devonian, (2) Middle Devonian through Triassic and probably Early Jurassic, and (3) Middle Jurassic through Holocene.

Principal reservoir rocks in the Timan-Pechora Basin Province include Upper Ordovician carbonates, Lower Silurian carbonates, Upper Silurian and Lower Devonian platform carbonates, Middle Devonian siliciclastic rocks, Upper Devonian reef carbonates, Carboniferous and lower Permian platform and reef carbonates, and upper Permian and Triassic siliciclastic rocks (Pairazain, 1993; Dedeev and others, 1994; Zhemchugova and Schamel, 1994; Fossum and others, 2001; Kaufman and Jameson, 2002). Nearly all the petroleum reservoirs are within structural traps; however, potential reservoirs in stratigraphic traps are virtually untested and might be future exploration targets.

\section{Domanik-Paleozoic Total Petroleum System}

The Domanik-Paleozoic Total Petroleum System (TPS) was defined by Lindquist (1999) and Ulmishek (2000) to encompass discovered and undiscovered oil and gas accumulations in the Timan-Pechora Basin Province (fig. 5). The name "Domanik" refers to what is interpreted to be the principal petroleum-source-rock facies-Upper Devonian (Frasnian) organic-rich mudstones in this TPS, and the term "Paleozoic" refers to the general age of the reservoirs.

\section{Petroleum Source Rocks}

In an extensive discussion of petroleum source rocks, Ulmishek (1982) concluded that several stratigraphic intervals, ranging in age from Ordovician through Permian, were established or otherwise potential petroleum source rocks. However, the geochemical data available at that time were heavily biased toward the Upper Devonian Domanik interval, whereas data were unavailable to adequately characterize other Paleozoic potential source rocks.

Ulmishek (1982) made a critical distinction between the Domanik Formation (Late Devonian, also called the Semiluki horizon) and a Domanik-type facies in the Timan-Pechora Basin that ranges in age from Upper Devonian through lower Carboniferous (Tournasian), whereas the Domanik Formation is restricted to the Upper Devonian (Frasnian). The Domanik Formation contains bituminous limestone, marl, shale, chert, and fine-grained limestone, whereas the more generally defined Domanik-type facies contains alternating black limestone, marl, siliceous limestone, and shale, some of which is bituminous (Abrams and others, 1999). 


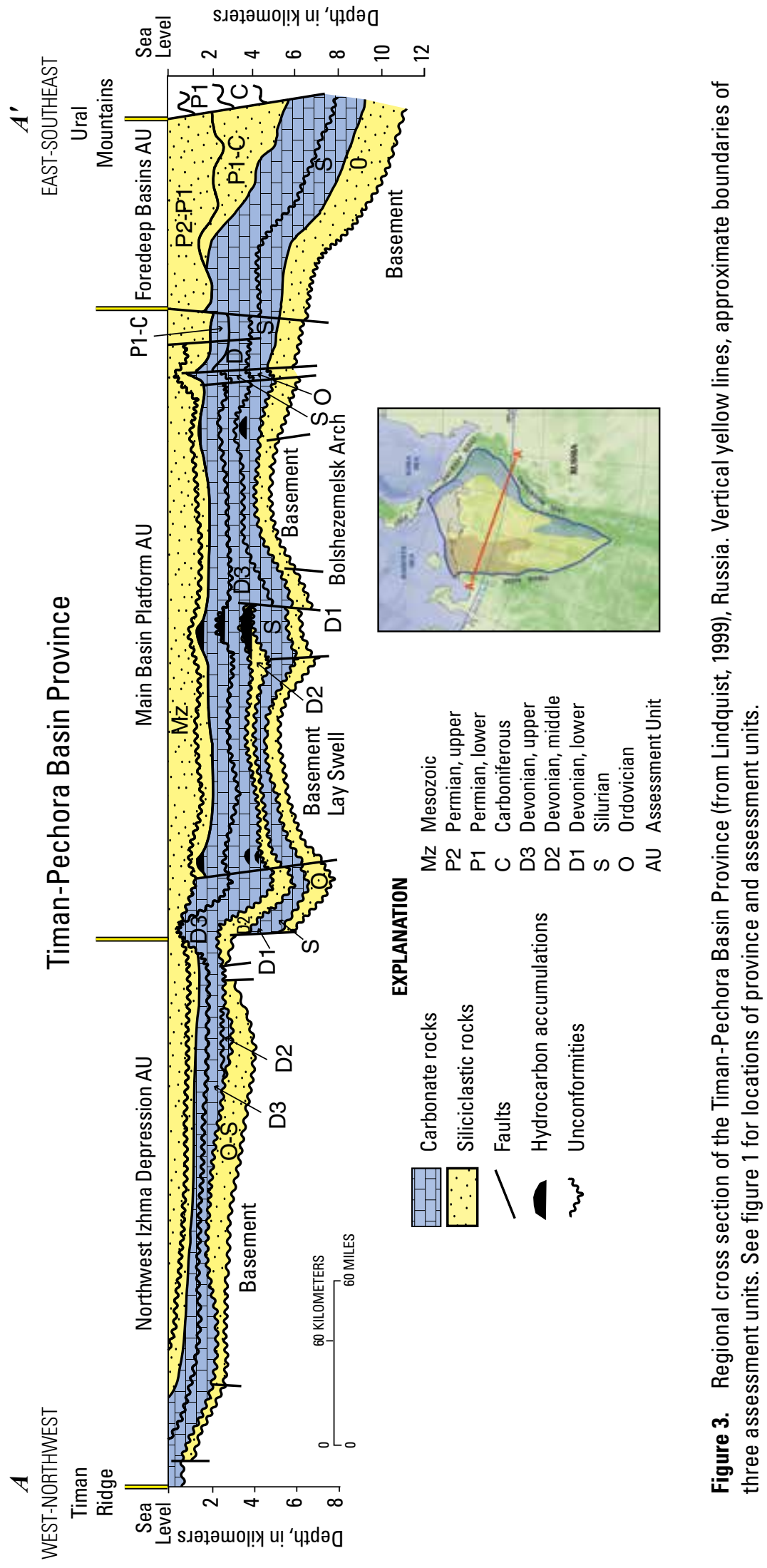




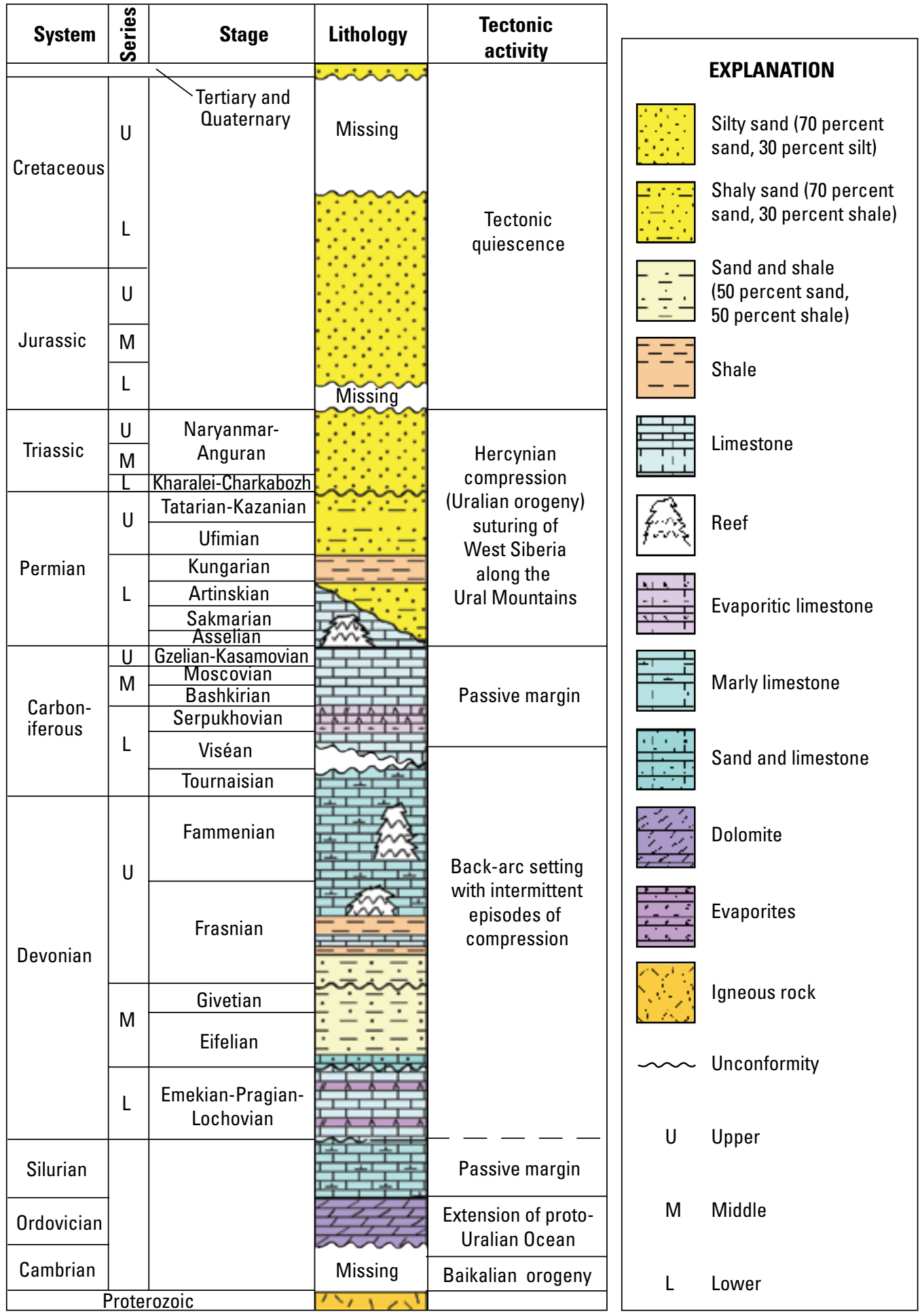

Figure 4. Stratigraphic column for the Timan-Pechora Basin Province (modified from Abrams and others, 1999), Russia. 


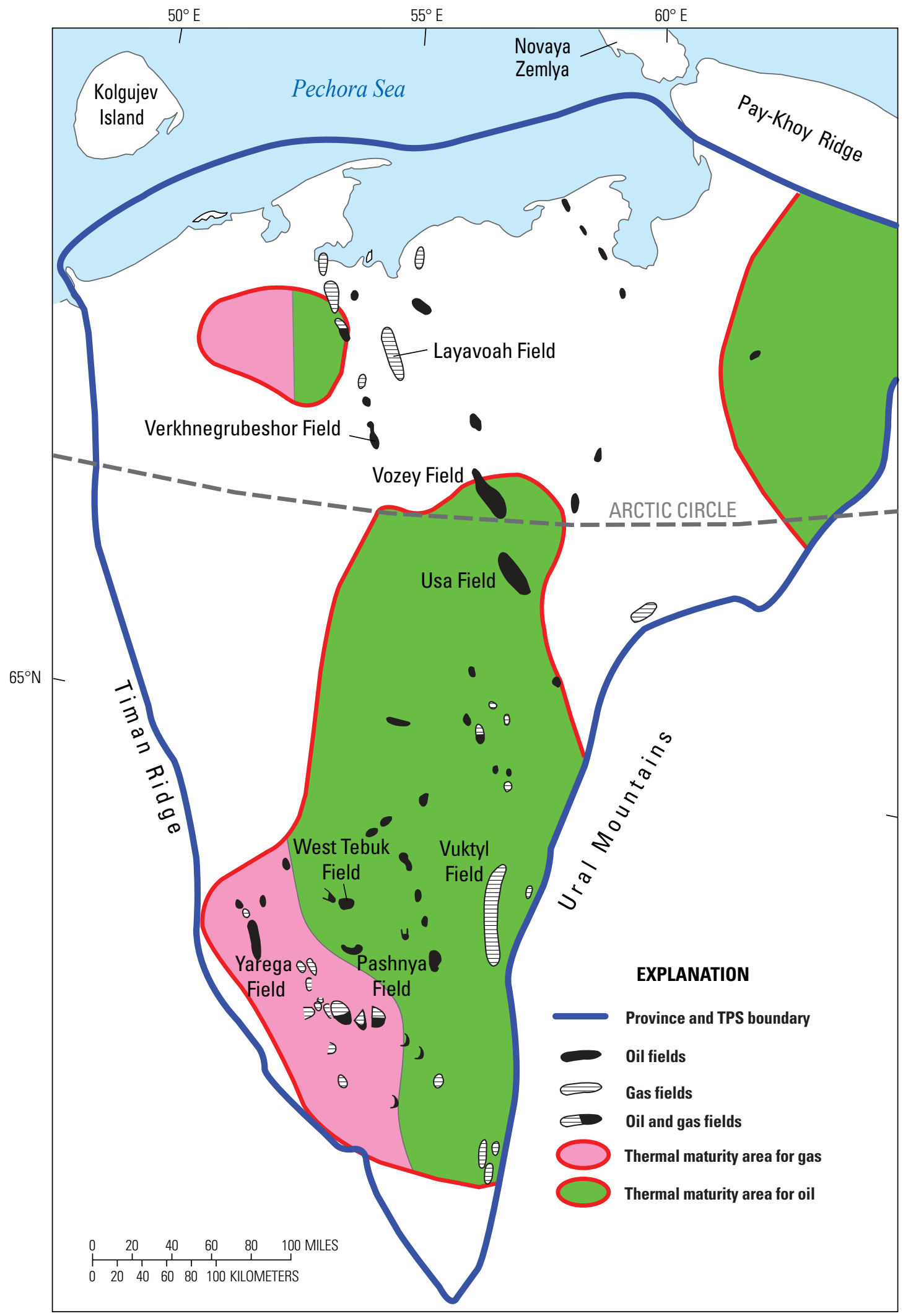

Figure 5. Total petroleum system (TPS) map of the Timan-Pechora Basin Province, Russia. Thermally mature areas are the Devonian Domanik Formation (modified from Ulmishek, 1982). 
Requejo and others (1995) analyzed 36 oil samples and concluded that four types of oil are present in the TimanPechora Basin Province; however, they were unable to correlate these oils with specific source rocks. Two types are sulfur rich, typical of oils from carbonate-evaporite source rocks; the third type appears to have been derived from an Ordovician source rock; and the fourth type likewise was not correlated to any specific source rock. An important conclusion from their study was that significant mixing of oils occurred in the province as a result of tectonics and vertical migration along faults.

The geochemistry of several oils from the northeastern part of the Timan-Pechora Basin Province was summarized by Abrams and others (1999), who concluded that three geochemical oil families are present in this part of the basin: A, which was sourced by marine type II organic matter from bitumen-laminated carbonate mudstones of the Domanik-type facies; B, which was sourced from Upper Devonian marine mudstone deposited in a hypersaline environment; and C, which was sourced from Silurian and Lower Devonian mudstone (Abrams and others, 1999).

Abrams and others (1999) demonstrated a relation between the structural complexity in a small area of the Timan-Pechora Basin Province and the resulting variations in locally important oil families. They concluded that the complex areal distribution of the various petroleum source rocks, the variations in burial depths, and thermal maturation led to a spectrum of generation, migration, and accumulation scenarios even in this small area.

In their analysis of the Timan-Pechora Basin Province for undiscovered oil and gas potential, Fossum and others (2001) concluded that at least five oil families, representing five different source rocks, are present: (1) Middle and Upper Ordovician through Lower Devonian (Type II marine organic matter), (2) Middle Devonian (Type II marine organic matter in the east, Type III in the west), (3) Upper Devonian (Type II marine organic matter), (4) middle Frasnian (Domanik) through Carboniferous (type of organics not cited), and (5) lower Permian (Type III marine organic matter). Each of these intervals averages $>2$ weight percent total organic carbon (TOC) content. On the basis of available data, Fossum and others concluded that the two most significant source-rock intervals with respect to volumes generated are (1) Middle and Upper Ordovician through Lower Devonian (Type II marine organic matter) and (2) middle Frasnian (Domanik) through Carboniferous. Their study also demonstrated that the diverse structural and thermal evolution of the various elements of the Timan-Pechora Basin led to a complex history of petroleum generation, migration, and accumulation.

In contrast, Gordadze and Tikhomirov (2006) concluded that only four oil families are represented in the TimanPechora Basin Province, on the basis of a detailed examination of petroleum biomarkers; Type I, sourced from bituminous limestone of the Domanik Formation; Type II, sourced from Domanik-type facies; Type III, sourced by Silurian and Lower Devonian shale; and Type IV, from multiple sources, including Silurian rocks and the Domanik-type facies. Like Fossum and others (2001), Gordadze and Tikhomirov also concluded that the history of petroleum generation and vertical migration in the Timan-Pechora Basin Province was complex. In general, the oil families defined by Gordadze and Tikhomirov are similar to those defined by Requejo and others (1995) and Abrams and others (1999).

Bogatsky and Pankratov (1993) concluded that, in the central part of the Timan-Pechora Basin, several stages of oil and gas generation and migration have occurred, with possible degassing of reservoirs during uplift. Tectonics also caused the loss of petroleum from some structures and the degradation of some pooled hydrocarbons. The complexity of oil and gas generation and migration was also discussed by Lodzhevskaya and Smolenchuk (1998).

\section{Timing of Thermal Maturation}

The timing of source-rock maturation involves an estimation of when a source-rock interval attains a thermal exposure sufficient for oil and gas generation. Focusing on Upper Devonian source rocks, Ulmishek (1982) concluded that these rocks reached thermal maturation for oil in the platform area of the Timan-Pechora Basin during the Triassic and Early Jurassic. Carboniferous source rocks reached thermal maturation for oil across much of the basin contemporaneously; however, source rocks in the foredeep adjacent to the Uralian fold and thrust belt reached thermal maturation in the early Permian for oil and in the late Permian for gas. Ulmishek (1982) did not discuss the timing of thermal maturation of the Ordovician through Lower Devonian source rocks, which would have reached thermal maturation earlier. The Ordovician and Silurian section consist of significant stratal thicknesses that might have reached thermal maturation as early as the Carboniferous (Pairazain, 1993). Burial-history modeling of five locations in the province by Pairazain (1993; also shown by Lindquist, 1999) indicates that thermal maturation in most areas was reached in the Carboniferous rather than in the Permian and Triassic. Thermal maturation in the foredeep is interpreted to have been reached even earlier than the Carboniferous (Pairazain, 1993).

Abrams and others (1999) concluded that the onset of oil generation in the northeastern part of the Timan-Pechora Basin Province (using Upper Devonian source rocks as an example) began in the Middle Jurassic, with peak generation reached in the Late Jurassic. This model was constrained and calibrated by using vitrinite reflectance data.

Given the structural complexity, multiple rifting events, inversion, compression, and varying source-rock geochemistry, it is not surprising that burial-history models constructed for one area vary with respect to the timing of petroleum generation and migration in comparison with models constructed for other areas with a different geologic history. Source rocks in older, deeper grabens generated petroleum earlier than those in younger, shallower grabens, and the thermal exposure of these older source rocks was overprinted by foredeep burial during the Permian and Triassic. 
Law and others (1996) and Law (2002) concluded that an unconventional, basin-centered gas system exists in the foredeep basins. According to them, lower and middle Permian rocks include as much as 2,000 $\mathrm{m}$ of sandstone, coal, siltstone, and mudstone, with a TOC content as high as 4 weight percent. Much of this section is overpressured, possibly because of gas generation and trapping in low-permeability rocks. This self-sourced, unconventional gas system, supposedly centered in the Kosyu-Rogov Trough of the foredeep (fig. 1), is interpreted to extend throughout most of the foredeep and, possibly, along the length of the Ural fold and thrust belt (Law and others, 1996). This potentially vast unconventional gas resource was not omitted from this assessment of conventional resources.

Where the organic-rich Domanik-type facies source rock is in the thermal window for oil generation, this source rock might also be a reservoir for unconventional oil, similar to the Bakken Formation of North Dakota (Pollastro and others, 2008). Unconventional oil was not assessed in this study.

\section{Summary}

The Domanik-Paleozoic TPS is a composite structure with at least five petroleum-source rocks of Ordovician through Permian age that might have contributed petroleum to traps within the Timan-Pechora Basin Province. Source rocks are interpreted to be thermally mature for both and oil and gas; source rocks in the foredeep are interpreted to have been in the gas-generation window. Timing of petroleum generation is difficult to generalize, owing to structural complexity and the tectonic and stratigraphic history of the province. The foredeep might be the site of an extensive basin-centered gas system similar to the gas systems in foredeep basins described in the United States (Law, 2002).

Ulmishek (1982) presented a thermal-maturation map of the Devonian Domanik Formation in the Timan-Pechora Basin Province. According to his interpretation, most of this formation is within the gas-generation window (fig. 5), in which case Ordovician and Silurian source rocks would be as thermally mature as (or more so than) the Domanik, and Carboniferous and Permian rocks might be thermally mature for oil across much of the basin as well. The thermal-maturation map by Ulmishek (1982) indicates that oil or gas fields are absent in the Izhma-Pechora Depression, probably because of a paucity of source rocks in that area.

Dedeev and others (1994), in their discussion of the stratigraphic distribution of oil and gas accumulations in the Timan-Pechora Basin Province, concluded that (1) although several potential source rocks are present, many early-formed accumulations could have been affected by subsequent structural inversion; and (2) only a small fraction of the oil generated in the basin remains trapped because most of the oil and gas either was never trapped or was lost from degraded traps. However, they further concluded that oil and gas generation occurred over more than half the basin area, and that the main phase of generation coincided with the formation of structural traps during the Permian and Triassic.

\section{Assessment-Unit Descriptions}

The three AUs described in this report were adopted from an earlier oil and gas assessment of the Timan-Pechora Basin Province (Lindquist, 1999; Ulmishek, 2000), in which they were defined geologically and assessed for undiscovered resources. Because these AUs extend north of the Arctic Circle, they are being reassessed for the U.S. Geological Survey (USGS)'s Circum-Arctic Resource Appraisal program.

The three AUs designated in this report closely follow the structural domains outlined in the preceding discussion of the tectonic evolution of the Timan-Pechora Basin Province. The concept is that the structural evolution of the province is directly related to the formation of potential petroleum traps and systems. (1) The Northwest Izhma Depression AU was defined to include all potential structures and reservoirs in the northwestern part of the Izhma-Pechora Depression (fig. 1); however, this part of the basin probably contains little source or reservoir rock. (2) The Main Basin Platform AU was defined to include all potential structures and reservoirs that formed in the central part of the basin, where the tectonic and petroleum system evolution is complex. (3) The Foredeep Basins AU was defined to include all potential structures and reservoirs that formed within the thick sedimentary section of the foredeep basins during the Permian and Triassic Uralian orogeny.

\section{Northwest Izhma Depression Assessment Unit}

The Northwest Izhma Depression AU was defined to include all potential structures and reservoirs that formed in the northwestern part of the Izhma-Pechora Depression (fig. 1). The west boundary of this AU is the Timan Ridge, its east and south boundaries abut the Main Basin Platform AU, and its north boundary coincides with the south boundary of the Kolguylev Terrace AU of the East Barents Shelf Province (T.R. Klett, oral commun., 2008). The area of the Northwest Izhma Depression AU is about $81,000 \mathrm{~km}^{2}$ (appendix 1).

\section{Geologic Model for Assessment}

For an oil or gas field of minimum size (50 million barrels of oil equivalent [MMBOE]) to form in the Northwest Izhma Depression AU, long-distance lateral migration of petroleum generated from the thermally mature Domaniktype facies or other petroleum source rocks in the adjacent Main Basin Platform AU would be required. The intervening regional northwest-trending structures (fig. 1) and the paucity of adequate carrier beds for petroleum, however, would inhibit such westward migration. The structures in the Northwest Izhma Depression AU are interpreted to be smaller than those typical of the other AUs in the Timan-Pechora Basin Province (Lindquist, 1999), and these factors combine to indicate only a small probability for the presence of an oil or gas field of minimum size. 


\section{Geologic Analysis of Assessment Unit Probability}

Charge Probability.-The convergence of several major unconformities led to an interpretation that the main petroleum-source rocks of the Timan-Pechora Basin Province are absent in the Northwest Izhma Depression AU (Lindquist, 1999). Given this interpretation, the probability for an adequate petroleum charge or for an oil or gas field of minimum size (50 MMBOE) in this AU is estimated at 20 percent, or 0.2 .

Rock Probability.-Structural traps were postulated for the Northwest Izhma Depression AU by Lindquist (1999). Adequate reservoir rocks and seals might exist within these structures; however, the presence of several unconformities points to possible erosion of reservoirs. The probability of adequate reservoir rocks, traps, and seals in this AU is estimated at 50 percent, or 0.5 .

Timing and Preservation Probability.-Given the probable absence of adequate petroleum-source rocks in the Northwest Izhma Depression AU, the occurrence of an oil and gas accumulation would require questionable long-distance migration from the Main Basin Platform AU through a structurally complex area, as well as an area with minimal carrier beds. Because of these unfavorable conditions, the probability for timing and preservation of an oil or gas field of minimum size in this AU is estimated to be 20 percent, or 0.2 .

The overall geologic probability for the presence of an oil or gas field of minimum size in the Northwest Izhma Depression AU is the product of the above three geologic probabilities, or 0.02 , indicating a 2-percent probability for the proper geologic conditions to form an oil or gas field of minimum size (50 MMBOE recoverable). Accordingly, the Northwest Izhma Depression AU was not quantitatively assessed for undiscovered resources (appendix 1) in the present study. In the 2000 assessment (Ulmishek, 2000), the minimum field size was much smaller (5 MMBOE compared with $50 \mathrm{MMBOE}$ in this assessment), and the potential for smaller fields was included in that assessment of the Timan-Pechora Basin Province.

\section{Main Basin Platform Assessment Unit}

The Main Basin Platform AU was defined to include all potential structures and reservoirs that formed in the central part of the Timan-Pechora Basin Province (fig. 1), including many of the named structural elements in the basin, such as the Khoreyves Depression, the Pechora-Kolva Aulacogen, the Kolva Swell, Pechora-Kozhva Swell, and the Bolshesyria Trough, all of which have a complex tectonic history.

\section{Geologic Model for Assessment}

The geologic model for the Main Basin Platform AU is for petroleum to have been generated from Ordovician, through possibly Permian rocks, and then to have migrated vertically into structural traps associated with the large regional northwest-trending structures (fig. 6). Stratigraphic traps might also be significant future exploration targets. Petroleum generation, migration, and accumulation occurred at various times; generation in deeper grabens may have occurred in the Carboniferous (fig. 7) or even earlier. Migration began later in the grabens filled with Permian sediment. Both oil and gas were generated. Petroleum may have remigrated because many of the extensional structures that formed during multiple rift events in early Paleozoic time were compressed and inverted by Devonian and Permian and Triassic deformation.

\section{Geologic Analysis of Assessment-Unit Probability}

Charge Probability.-Several petroleum source rocks reached sufficient thermal maturation to have generated and expelled petroleum in the Main Basin Platform AU, including Ordovician, Silurian, Devonian, and Permian intervals (Ulmishek, 1982). Petroleum may have remigrated during Devonian as well as Permian and Triassic compressional events. The probability for the formation of an oil or gas field of minimum size (50 MMBOE) in this AU is estimated at 100 percent, or 1.0 .

Rock Probability.-More than 200 oil and gas discoveries of varying sizes, in reservoirs ranging from Ordovician through Triassic in age, have been reported for the Main Basin Platform AU. The lithology of the reservoirs ranges from platform and reef carbonates to siliciclastic deltaic and marine sandstones. The probability for the presence of adequate reservoir and seal rocks for an oil or gas field of minimum size in AU-2 is estimated at 100 percent, or 1.0.

Timing and Preservation Probability.-Given that $\geq 200$ oil and gas fields have been discovered in the Main Basin Platform AU, timing and preservation are not considered to be a source of geologic risk for the presence of an undiscovered oil and gas field of minimum size. Although most of the extensional structures in the Main Basin Platform AU were subsequently inverted by compression during the Permian and Triassic Uralian orogeny, this event apparently did not significantly affect the accumulation and preservation of petroleum in structural traps. Although timing would also have been adequate for the preservation of petroleum in stratigraphic traps, the probability for the formation of a stratigraphic trap to give rise to an oil or gas field of minimum size in the Main Basin Platform AU cannot be estimated because of insufficient exploration for such traps (Ulmishek, 1982). The overall geologic probability for the presence of an oil or gas field of minimum size in this AU is the product of the three geologic probabilities, or 1.0, indicating a 100-percent probability for the proper geologic conditions to form an oil or gas field of minimum size (50 MMBOE) recoverable in the Main Basin Platform AU.

A chart summarizing the timing of petroleum-system events in the Main Basin Platform AU is shown in figure 8, and a basin-evolution chart is presented in appendix 2 . The assessment input data are summarized in appendix 3. 


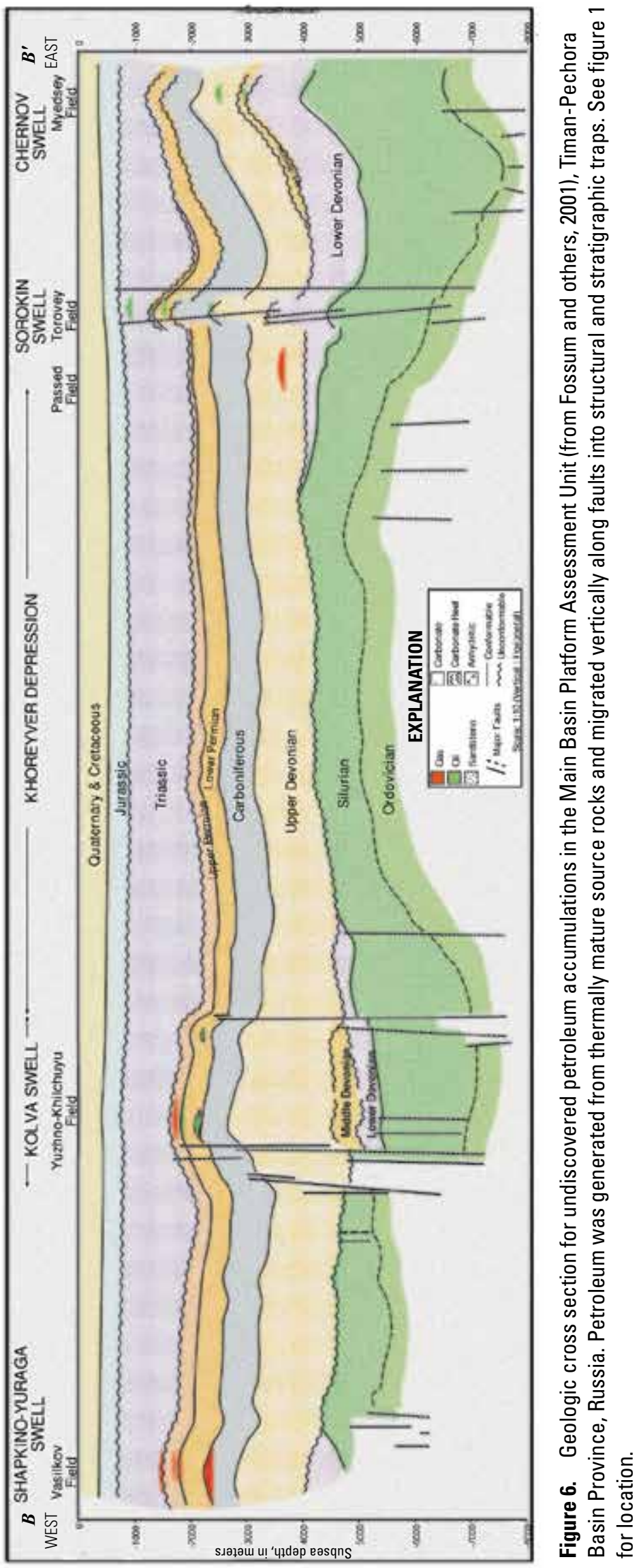




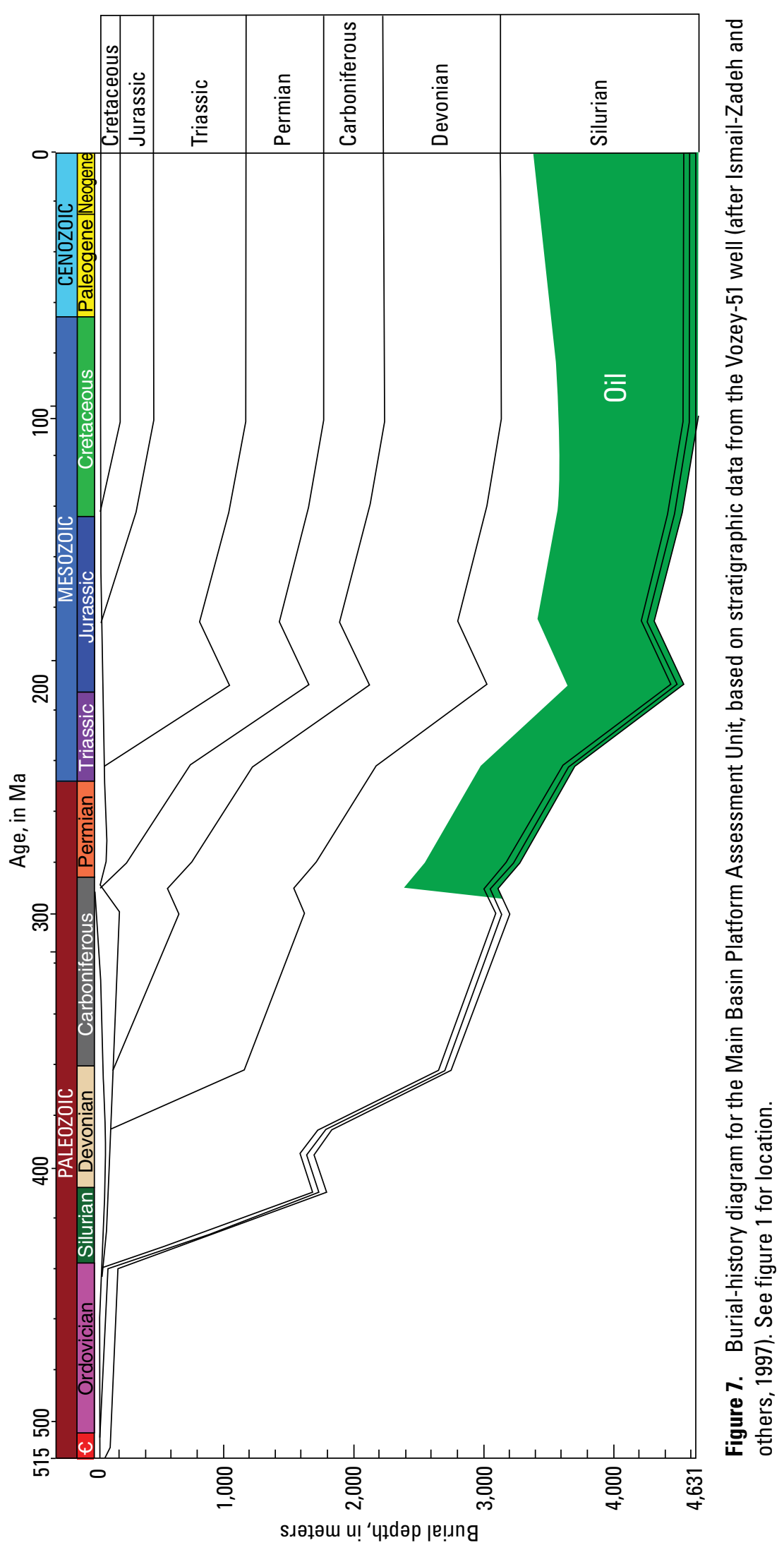




\author{
Timan-Pechora Basin Province \\ Domanik-Paleozoic Total Petroleum System \\ Main Basin Platform Assessment Unit
}

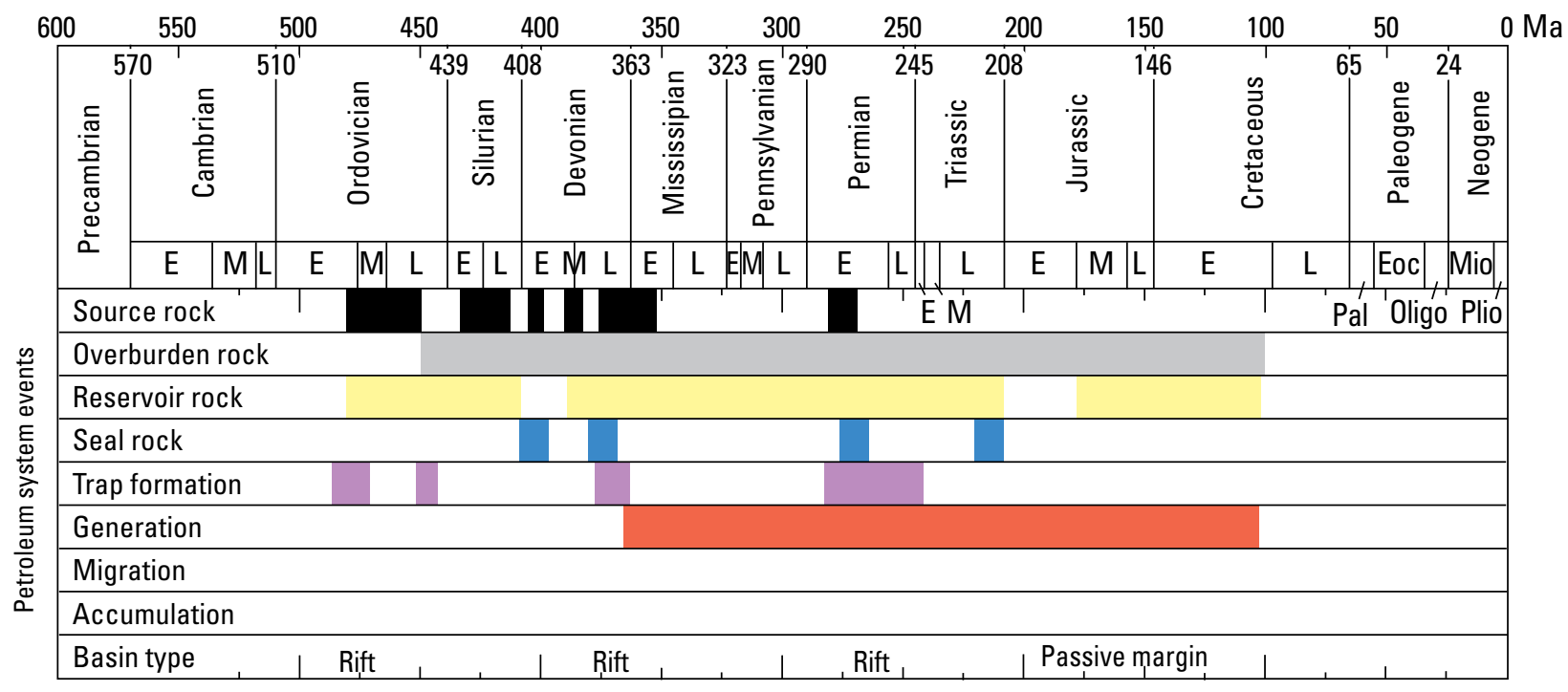

Figure 8. Chart of Total Petroleum System events in the Main Basin Platform Assessment Unit, Timan-Pechora Basin Province, Russia. E, early; Eoc, Eocene; L, late; M, middle; Mio, Miocene; Olig, Oligocene; Pal, Paleocene; Plio, Pliocene.

\section{Estimation of the Sizes and Numbers of Undiscovered Oil and Gas Fields}

The assessment of the Main Basin Platform AU primarily utilized the data for sizes and numbers of discovered oil and gas fields from the IHS Energy Group (2007) oil and gas field database. In comparison, the Structural Setting-Compressional Analog Set of Charpentier and others (2008) was evaluated for the sizes and numbers of undiscovered oil and gas fields because this dataset reflects traps in fields that have been formed largely by compression. The coproduct ratios and ancillary data were based largely on data from discovered oil and gas fields in the Main Basin Platform AU and, where necessary, from the World Averages Analog Set (Charpentier and others, 2008).

Numbers of Undiscovered Oil and Gas Felds.-The distribution of the numbers of undiscovered oil and gas fields is based on an analysis of discovered fields in the Main Basin Platform AU (fig. 9). Given its discovery history, with 54 oil fields larger than the minimum size of $50 \mathrm{MMBOE}$ (fig. $9 A$ ), the number of undiscovered oil fields is estimated to be a minimum of 1 , a median of 25 , and a maximum of 72 . On the basis of the discovery of 10 gas fields known to be larger than the minimum size of $300 \mathrm{BCFG}$ (fig. 9B), the number of undiscovered gas fields was estimated to be a minimum of 0 , a median of 8 , and a maximum of 40 (appendix 3 ).

The density of oil and gas fields was estimated from the Structural Setting-Compressional Analog Set of Charpentier and others (2008). The median density of oil and gas fields of all analog AUs reported in this dataset is 0.24 fields per $1,000 \mathrm{~km}^{2}$. Using the AU area of $210,000 \mathrm{~km}^{2}$, this analog field density yields a median estimate of 50 undiscovered oil and gas fields. The maximum number of undiscovered fields was calculated by using a density of $\sim 0.5$ fields per $1,000 \mathrm{~km}^{2}$, yielding a maximum of 105 undiscovered oil and gas fields. This analysis of undiscovered fields using geologic analogs indicates that the density of fields for the Main Basin Platform AU is probably at the high end of the range of densities from the analog dataset.

An analysis of discovered oil and gas fields shows that petroleum fluids consist more of oil than of gas, with the probability of undiscovered oil fields estimated at a minimum of 50 , a mode of 85 , and a maximum of 90 percent. This range reflects the uncertainty as to the type of petroleum logged as drilling deepens over time. This distribution of oil/gas mix was then used to estimate a minimum of 1 , a median of 25 , and a maximum of 72 undiscovered oil fields, and a minimum of 0 , median of 8, and a maximum of 40 undiscovered gas fields in this AU.

Sizes of Undiscovered Oil and Gas Fields.-The sizes of undiscovered oil and gas fields were estimated by using the sizes of existing fields in the Main Basin Platform AU. An analysis of grown oil-field sizes (fig. 9A) indicates a high probability that the largest oil field has already been discovered, given that the discovery process generally shows that field sizes decrease as exploration proceeds. The median size of undiscovered oil fields is estimated at $\sim 80$ MMBOE, given that the median sizes of existing fields in this $\mathrm{AU}$ are $>50 \mathrm{MMBO}$. The median gas-field size was estimated at 660 BCFG.

The maximum oil field size at 0 probability was estimated by using an analysis of the sizes of discovered fields. On this basis, the "largest expected oil field" at 0 probability 

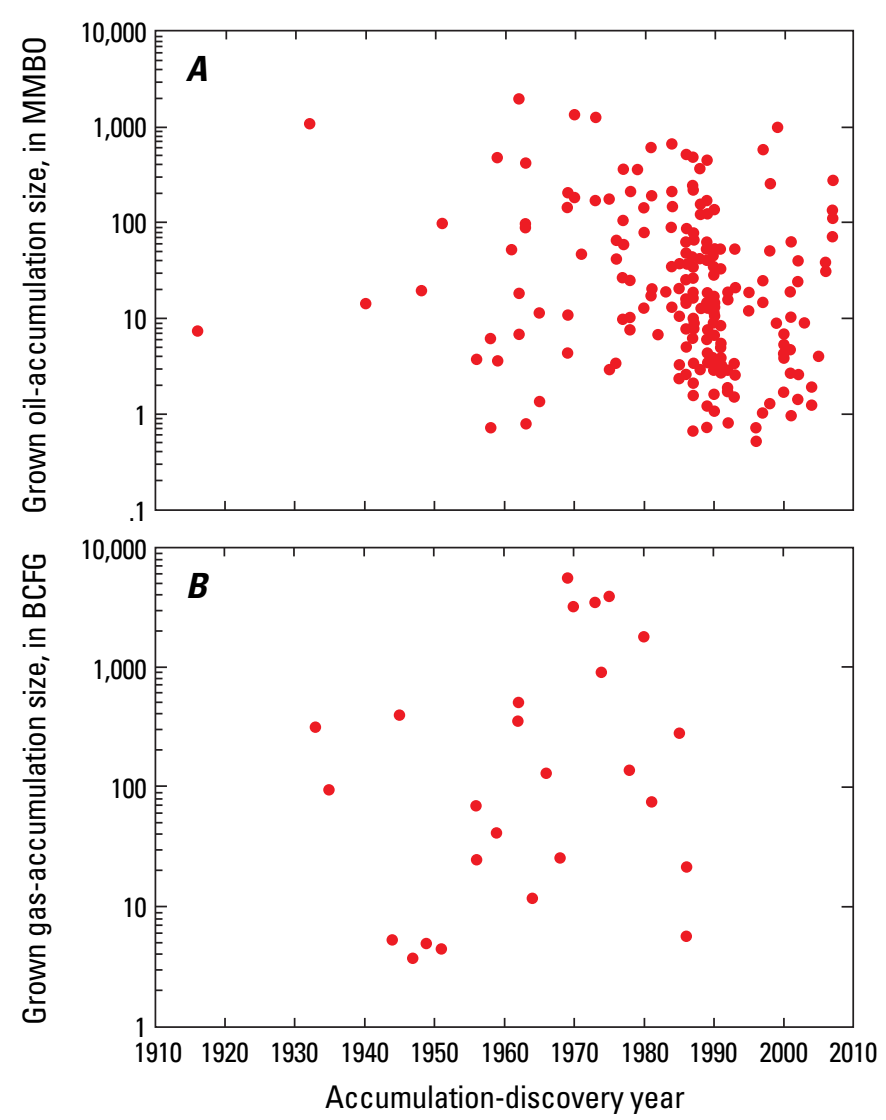

Figure 9. Graphs showing grown sizes and numbers of oil and gas fields in the Main Basin Platform Assessment Unit, Timan-Pechora Basin Province, Russia. A, Grown sizes of oil fields versus discovery year. $B$, Grown sizes of gas fields versus discovery year. MMBO, million barrels of oil; BCFG, billion cubic feet of gas. Data from IHS Energy Group (2007).

was estimated at $\sim 550 \mathrm{MMBO}$, leading to an estimated field size of $\sim 2,000 \mathrm{MMBO}$. Thus, the distribution of sizes of undiscovered oil fields at 0 probability is a minimum of 50 , a median of 80 , and a maximum of 2,000 MMBO. On the same basis, the "largest expected gas field" size at 0 probability was estimated to be $\sim 1,400 \mathrm{BCFG}$, leading to an estimated field size of $\sim 6,000$ BCFG. In summary, the distribution of sizes of undiscovered gas fields at 0 probability is a minimum of 300 , a median of 600 , and a maximum of 6,000 BCFG (appendix 3).

\section{Coproduct Ratios and Ancillary Data}

Coproduct ratios (gas/oil, natural gas liquids [NGL]/ oil, liquids/gas) were estimated from the data for discovered oil and gas fields. The median gas/oil ratio for undiscovered fields was estimated at 1,000 cubic feet of gas per barrel of oil (CFG/BO), the median NGL/gas ratio at 20 barrels of NGL per million cubic feet of gas (BNGL/MMCFG), and the median liquids/gas ratio in undiscovered gas fields at 20 barrels of liquids per million cubic feet of gas (BLIQ/MMCFG).
Ancillary data were derived from the data for discovered oil and gas fields.

Drilling depths for undiscovered oil and gas fields, based on data from all fields and water depths within the Main Basin Platform AU, were estimated from publically available bathymetric maps. The distribution of drilling depths for undiscovered oil fields is a minimum of $1,200 \mathrm{~m}$, a median of $2,500 \mathrm{~m}$, and a maximum of $4,000 \mathrm{~m}$. The distribution of drilling depths for undiscovered gas fields is a minimum of $500 \mathrm{~m}$, a median of $3,000 \mathrm{~m}$, and a maximum of $4,500 \mathrm{~m}$. The distribution of water depths for undiscovered oil and gas fields is a minimum of 0 , a median of $10 \mathrm{~m}$, and a maximum of $30 \mathrm{~m}$.

\section{Foredeep Basins Assessment Unit}

The Foredeep Basins AU was defined to include all potential reservoirs and reservoirs that formed within the thick sedimentary section of the foredeep basins west of the Uralian fold and thrust belt during the Permian and Triassic Uralian orogeny (fig. 1). This AU is bounded to the west by the Main Basin Platform AU, on the north by the south boundary of the Kolgulev Terrace AU of the adjoining East Barents Basin Province (T.R. Klett, oral commun., 2008), and on the east by the Ural Mountains (fig. 1). The area of the Foredeep Basins $\mathrm{AU}$ is $\sim 88,000 \mathrm{~km}^{2}$. Its definition and extent are identical to those used in the 2000 assessment (Lindquist, 1999; Ulmishek, 2000).

\section{Geologic Model for Assessment}

The geologic model used in the assessment of the Foredeep Basins AU is for petroleum to have been generated from Ordovician, Silurian, Devonian, and, possibly, Mesozoic source rocks within the deeper parts of the foredeep and then to have migrated vertically into preorogenic and postorogenic reservoirs (fig. 10). Burial of the source rocks in successive stages during the formation of the foredeep led to continued petroleum maturation. Foredeep burial might have caused the older source rocks to enter into and possibly progress through the gas thermal window. The most likely reservoirs are clastic rocks in structural traps associated with the Uralian compression. Reefs might be potential reservoirs in the pre-Uralian section (Zhemchugova and Schamel, 1994).

\section{Geologic Analysis of Assessment Unit Probability}

Charge Probability. - Charge was not considered to be a source of geologic risk in the Foredeep Basins AU because several source rocks are present and burial was sufficient for petroleum generation in the pre-Uralian section before Uralian burial and in most units after deformation. The presence of several source rocks and at least two gas accumulations larger than the minimum size of $300 \mathrm{BCFG}$, including a giant gas field (19 trillion cubic feet of gas [TCFG]), indicates no risk on the charge to form a field of minimum size in this AU; accordingly, the charge probability was estimated at 100 percent, or 1.0 . 


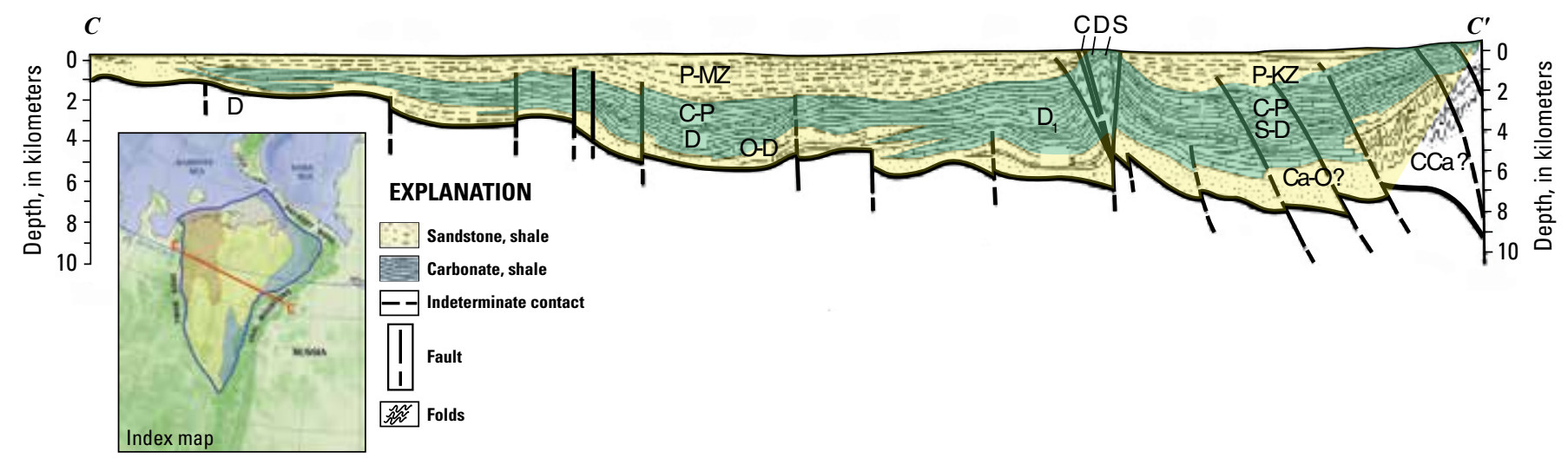

Figure 10. Geologic cross section for undiscovered petroleum accumulations in the Foredeep Basins Assessment Unit, Timan-Pechora Basin Province, Russia (after Ismail-Zadeh and others, 1997). Petroleum was generated from thrust loading and foredeep burial and migrated into structural traps in foredeep basins. Ca, Cambrian; 0, Ordovician; S, Silurian; D, Devonian; C, Carboniferous; P, Permian; T, Triassic; K, Cretaceous; MZ, Mesozoic; KZ, Cenozoic; Q, Quaternary. See figure 1 for location.

Rock Probability.-Most potential petroleum reservoirs in the Permian and Triassic section of the Foredeep Basins AU are in siliciclastic rocks of low permeability (Law and others, 1996). Reservoirs in the Ordovician through Carboniferous section are in carbonate rocks that have been deeply buried by Uralian foredeep sediment. Seals in the siliciclastic section may be a source of geologic risk for conventional oil or gas accumulations. For these reasons, the probability of adequate reservoir rocks and seals to form a field of minimum size in this AU is estimated at 60 percent, or 0.6.

Timing and Preservation Probability.-The compressional structural regime of the foredeep basins caused inversion of earlier rift-related extensional structures, most of which probably contained petroleum before foredeep formation. Although inversion might have caused some remigration of petroleum, this process was not considered a significant factor in assigning geologic risk, and so the probability of timing and preservation in the Foredeep Basins AU is estimated at 90 percent, or 0.9 . The burial-history model (fig. 11) was constructed by using the maximum thickness of sedimentary units in the foredeep to determine the earliest possible timing of petroleum generation. This model indicates that oil generation could have begun in Late Ordovician or Silurian time, and onset of gas generation likely occurred in the Carboniferous, using reasonable values for heat flow over time. The overall geologic probability is 0.54 , which is the product of the three geologic probabilities, indicating a 54-percent probability that an undiscovered oil or gas field of minimum size (50 MMBOE) is present in the Foredeep Basins AU.

A chart summarizing the petroleum-system events in the Foredeep Basins AU is shown in figure 12, and the basinevolution chart is presented in appendix 4 . The assessment input data are summarized in appendix 5 .

\section{Estimation of the Sizes and Numbers of Undiscovered Oil and Gas Fields}

The Architecture-Rift-Sag Analog Set of Charpentier and others (2008) was used to estimate the numbers and sizes of undiscovered oil and gas fields in the Foredeep Basins AU, given that only two fields larger than the minimum size are present (fig. 13A). The Architecture-Rift-Sag Analog Set and the World Averages Analog Set (Charpentier and others, 2008) were used to estimate coproduct ratios and ancillary data.

Numbers of Undiscovered Oil and Gas Fields. - The median densities of oil and gas fields from the Structural SettingCompressional Analog Set and the Architecture-Foreland Analog Set are 0.18 and 0.24 fields per $1,000 \mathrm{~km}^{2}$, respectively, and so a density of 0.21 fields per $1,000 \mathrm{~km}^{2}$ was used, along with the AU area of $88,000 \mathrm{~km}^{2}$, to arrive at a median of 18 undiscovered fields. This number was decreased by the 2 discovered gas fields, leaving a median of 16 undiscovered fields. The maximum number of undiscovered fields was 55 , reflecting a density of 0.5 fields per $1,000 \mathrm{~km}^{2}$. Thus, the distribution of the numbers of undiscovered fields is a minimum of 1 , a median of 16 , and a maximum of 55 .

The data for gas-field sizes (fig. 13A) illustrate that of the 17 fields in the Foredeep Basins AU only two are larger than the minimum size of 300 BCFG. Gas accumulations are still are being discovered at greater depths with continued exploration (fig. 13B).

Most of the undiscovered petroleum resource is estimated to be gas. The minimum and mode of the oil/gas mix were estimated at 0 percent and the maximum at 15 percent. Using these estimates, the distribution of undiscovered oil fields was estimated at a minimum of 0 , a median of 1 , and a maximum of 8; and of undiscovered gas fields, a minimum of 1 , a median of 15 , and a maximum of 55 (see appendix 5). 


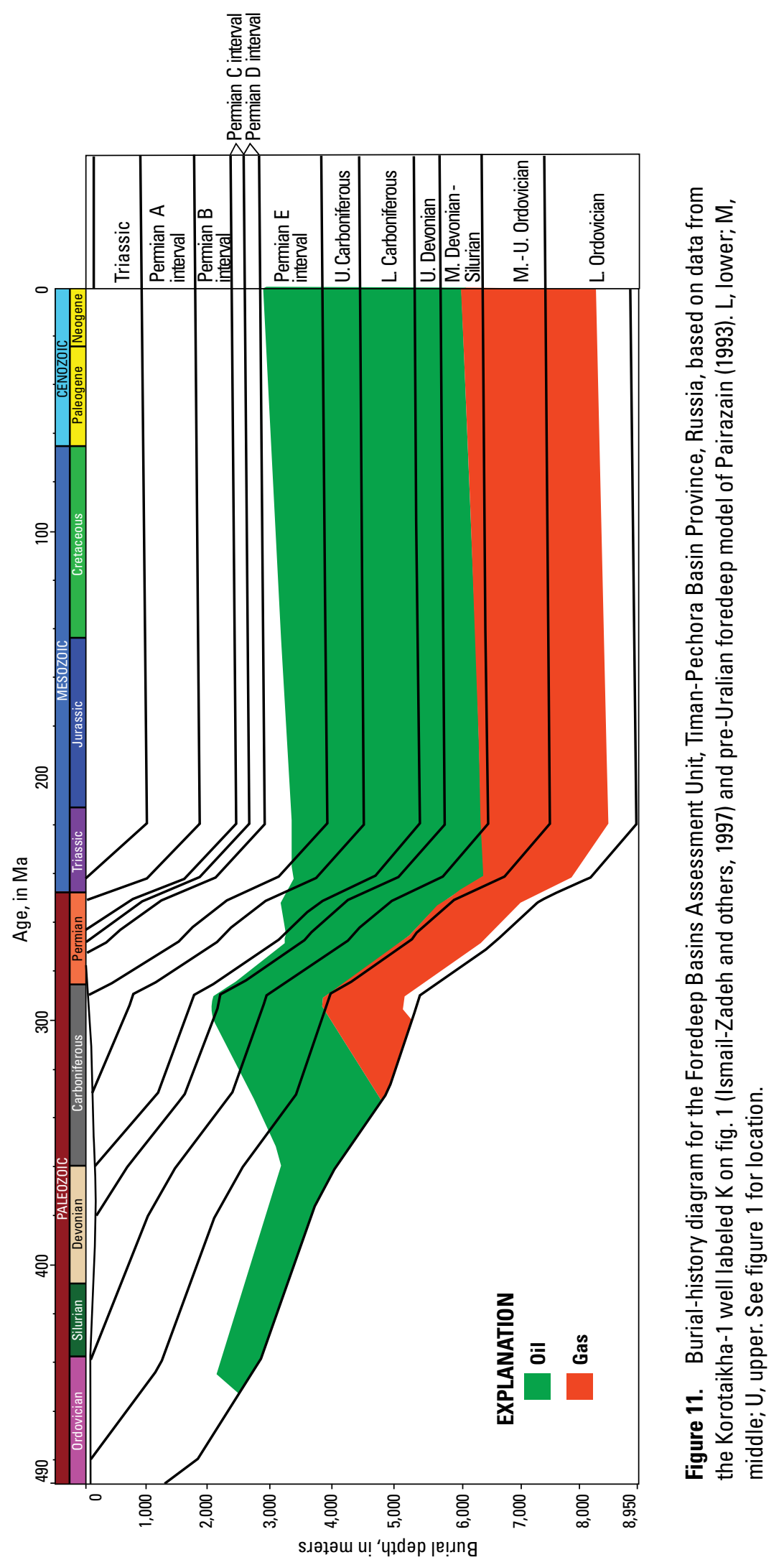


Timan-Pechora Basin Province

Domanik-Paleozoic Total Petroleum System

Foredeep Basins Assessment Unit

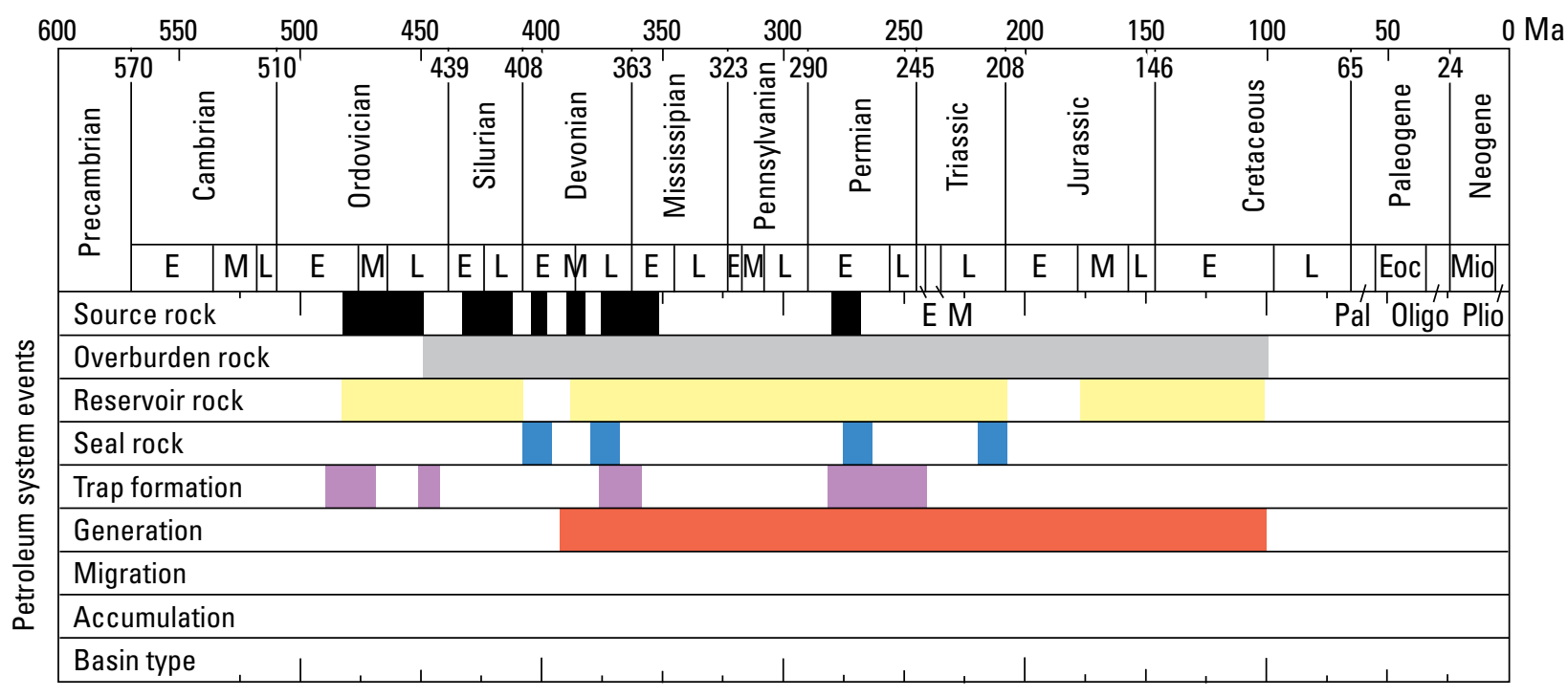

Figure 12. Chart of total-petroleum-system events in the Foredeep Basins Assessment Unit, Timan-Pechora Basin Province, Russia. E, Early; M, Middle; L, Late; Pal, Paleocene; Eoc, Eocene; Olig, Oligocene; Mio, Miocene; Plio, Pliocene.
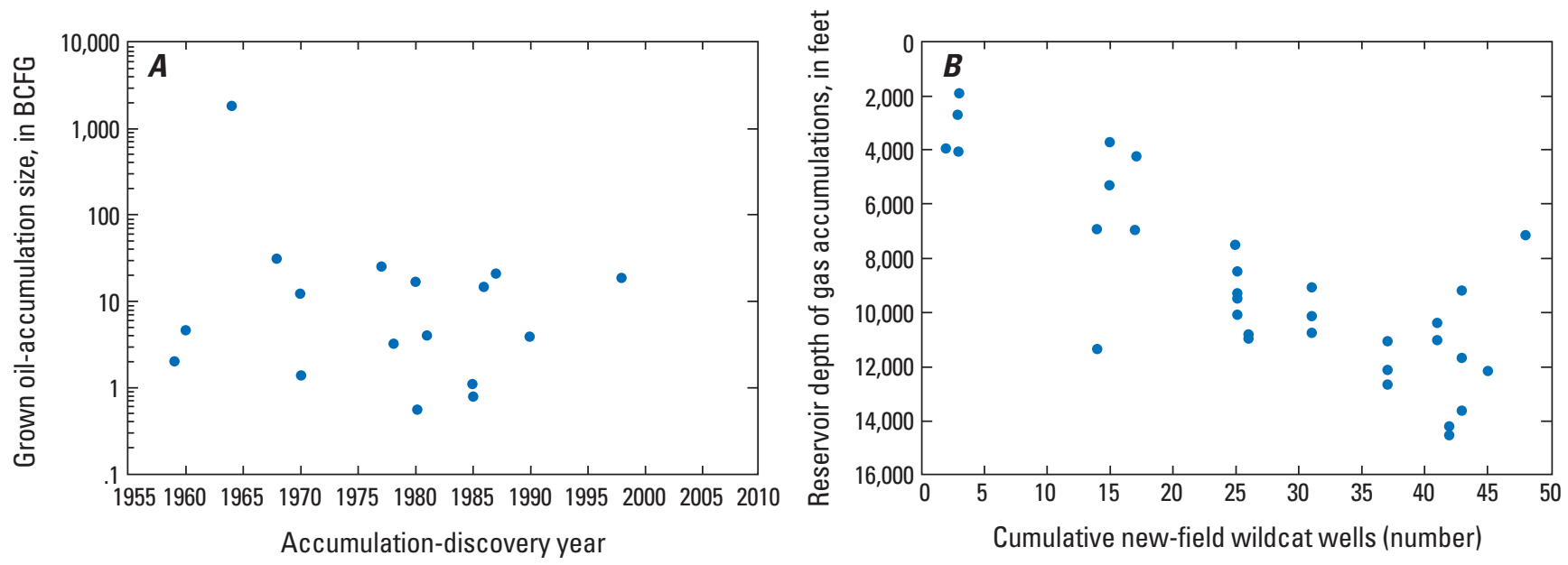

Figure 13. Grown sizes and numbers of gas fields in the Foredeep Basins Assessment Unit, Timan-Pechora Basin Province, Russia. A, Grown sizes of gas fields in the assessment unit. Most gas fields are smaller than the minimum size of 300 billion cubic feet of gas (BCFG) used in this assessment. $B$, Gas field discoveries versus depth of production. Note the general increase in reservoir depth over time. Data from IHS Energy Group (2007). 
Sizes of Undiscovered Oil and Gas Fields.-Estimation of the sizes of undiscovered oil and gas fields was guided by the Structural Setting-Compressional Analog Set and the Architecture-Foreland Analog Set. The median oil accumulation size was set at $110 \mathrm{MMBO}$, reflecting the median in both analog datasets. The "largest expected oil field size" was estimated at $\sim 160 \mathrm{MMBO}$, corresponding to a maximum oil-field size at 0 probability of $\sim 1,200 \mathrm{MMBO}$. Thus, the distribution of undiscovered field sizes at 0 probability is a minimum of 50 , a median of 110, and a maximum of 1,200 MMBO. Given a scale factor of 6 , the corresponding sizes of undiscovered gas fields are a minimum of 300, a median of 660 BCFG. The "largest expected gas field size" was estimated at $\sim 1,900 \mathrm{BCFG}$, corresponding to a maximum at 0 probability of 5,000 BCFG.

\section{Coproduct Ratios and Ancillary Data}

Coproduct ratios were estimated using the coproductratio summaries in the adjacent Main Basin Platform AU and data from the Structural Setting-Compressional Analog Set, and the Architecture-Rift Sag Analog Set (Charpentier and others, 2008). Ancillary data were derived primarily from the Main Basin Platform AU and the World Averages Analog Set (Charpentier and others, 2008). The median gas/oil ratio for undiscovered fields was estimated at 1,000 CFG/BO, the median NGL/gas ratio at $20 \mathrm{BNGL} / \mathrm{MMCFG}$, and the median liquids/gas ratio in undiscovered gas fields at $20 \mathrm{BLIQ/}$ MMCFG.

Drilling depths for undiscovered fields in the Foredeep Basins AU were estimated from published cross sections, and water depths within this AU were estimated from publically available bathymetric maps. Drilling depths for undiscovered oil fields were a minimum of $2,000 \mathrm{~m}$, a median of $4,000 \mathrm{~m}$, and a maximum of $5,500 \mathrm{~m}$; and for undiscovered gas fields, a minimum of 2,500 m, a median of 4,000 m, and a maximum of 7,000 m. Estimated water depths for undiscovered oil and gas accumulations are a minimum of 0 , a median of $10 \mathrm{~m}$, and a maximum of $20 \mathrm{~m}$.

\section{Assessment Results}

The assessment results for undiscovered conventional oil and gas resources in the three AUs in the Timan-Pechora Basin Province are summarized in table 1.

The Northwest Izhma Depression AU was not quantitatively assessed in this study as the probability for a field of minimum size was estimated at $<10$ percent. For the combined $\mathrm{AU}$ areas, the estimated means of undiscovered resources are (1) for the Main Basin Platform AU, 3,225 MMBO, 9,980 BCFG, and 226 MMBNGL; and (2) for the Foredeep Basin AU, 96 MMBO, 7,145 BCFG, and 158 MMBNGL. For the Timan-Pechora Basin Province, the estimated total mean of undiscovered oil estimate is $3,321 \mathrm{MMBO}$, the estimated mean of undiscovered gas is $17,125 \mathrm{BCFG}$, and the estimated mean of undiscovered NGL estimate is 384 MMBNGL.

For those parts of the AUs north of the Arctic Circle (fig. 1), the estimated means of undiscovered resources are (1) for the Main Basin Platform AU, 1,613 MMBO, 4,990 BCFG, and 114 MMBNGL; and (2) for the Foredeep Basin AU, 55 MMBO, 4,072 BCFG, and 90 MMBNGL. For the area of the Timan-Pechora Basin Province north of the Arctic Circle, the estimated mean of undiscovered oil is 1,668 MMBO, the mean undiscovered gas estimate is 9,062 BCFG, and the estimated mean of undiscovered NGL estimate is 204 MMBNGL.

Detailed assessment results for the Main Basin Platform AU and the Foredeep Basins AU are presented in appendixes 6 and 7.

The assessment results presented here reflect the state of geologic knowledge of the Timan-Pechora Basin Province at the time of the assessment. Future drilling and evaluation of the petroleum systems within the province will greatly add to the geologic knowledge base and lead to a refinement of these assessment results, especially for the unconventional basin-centered gas accumulation in the Foredeep Basins AU and, possibly, an unconventional oil accumulation in the Domanik Formation. 
Table 1. Assessment results (conventional undiscovered resources) for the Timan-Pechora Province.

[AU, assessment unit; BCF; billion cubic feet; MMB, million barrels; Results shown are fully risked estimates. For gas accumulations, all liquids are included under the natural gas liquids (NGL) category. F95, 95-percent probability of at least the amount tabulated, and so on for F50 and F5. Fractiles are additive under the assumption of perfect positive correlation. N/A, not applicable. Numbers do not exactly add to totals because totals were added by statistical aggregation]

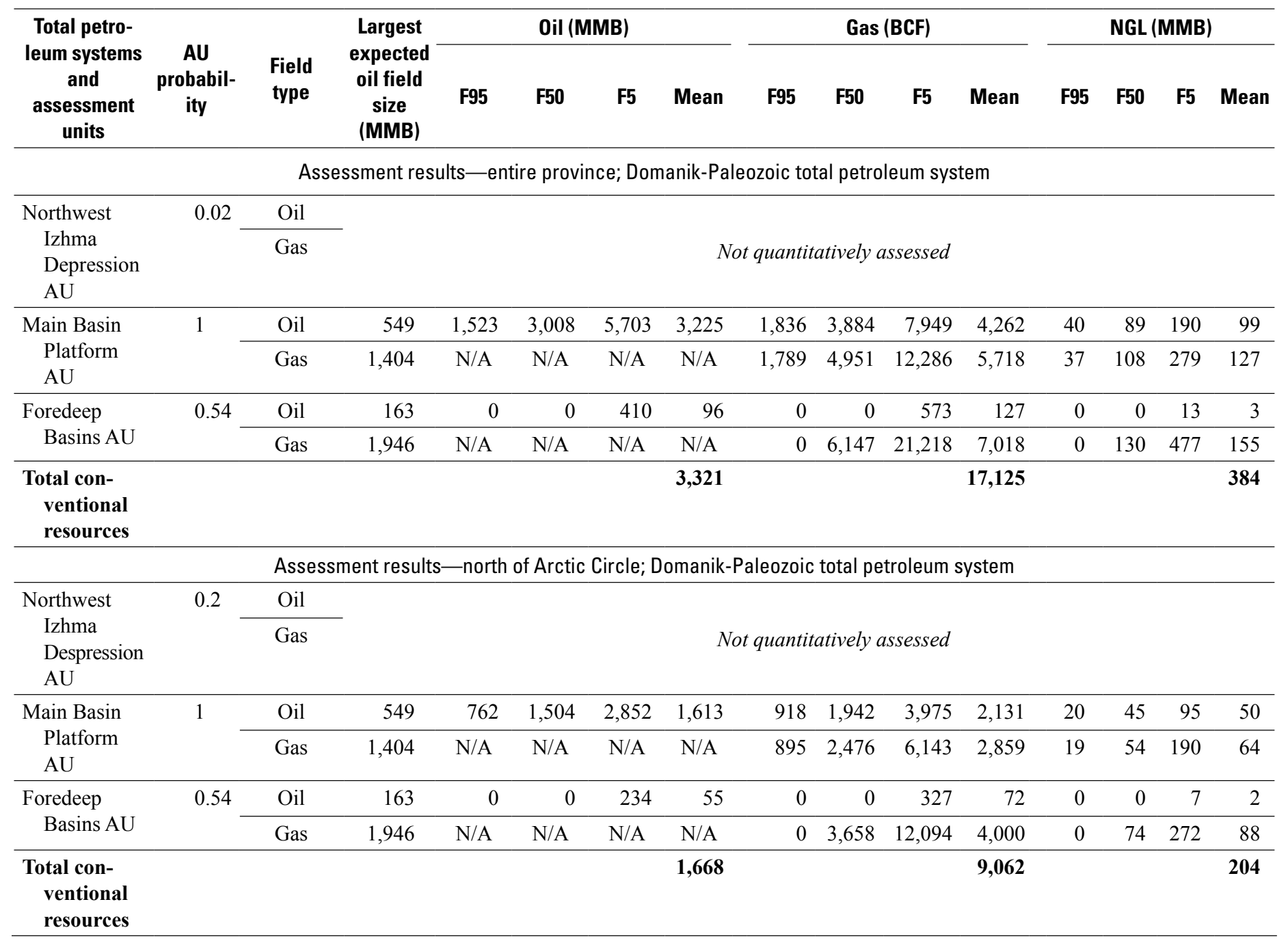




\section{References Cited}

Abrams, M.A., Apanel, A.M., Timoshenko, O.M., and Kosenkova, N.N., 1999, Oil families and their potential sources in the northeastern Timan-Pechora Basin, Russia: American Association of Petroleum Geologists Bulletin, v. 83 , no. 4 , p. 553-577.

Artyushkov, E.V., and Baer, M.A., 1986, Mechanism of formation of hydrocarbon basins - The West Siberia, VolgaUrals, Timan-Pechora and the Permian Basin of Texas: Tectonophysics, v. 122, p. 247-281.

Barrett, P.J., 2003, Paleoclimatology-Cooling a continent: Nature, v. 421, p. 221-223.

Bogatsky, V.I., and Pankratov, J.O., 1993, Controls on the distribution of oil, gas, and gas-condensate pools in the TimanPechora Basin [abs.]: American Association of Petroleum Geologists Bulletin, v. 77, no. 9, p. 1,608.

Charpentier, R.R., Klett, T.R., and Attanasi, E.D., 2008, Database for assessment unit-scale analogs (exclusive of the United States): U.S. Geological Survey Open-File Report 2007-1404, 61 p.

Clarke, J.W., 1994, The Timan-Pechora oil-gas basin-A geological review: International Geology Review, v. 36, p. 3-14.

Dedeev, V., Aminov, L., and Schamel, S., 1994, Stratigraphic distribution of oil and gas resources of the Timan-Pechora Basin: International Geology Review, v. 36, p. 24-32.

Fossum, B.J., Schmidt, W.J., Jenkins, D.A., Bogatsky, V.I., and Rappoport, B.I., 2001, New frontiers for hydrocarbon production in the Timan-Pechora Basin, Russia, in Downey, M.W., Threet, J.C., and Morgan, W.A., eds., Petroleum provinces of the twenty-first century: American Association of Petroleum Geologists Memoir, no. 74, p. 259-279.

Frakes, L.A., Francis, J.E., and Syktus, J.I., 1992, Climate modes of the Phanerozoic - The history of the Earth's climate over the past 600 million years: Cambridge, Cambridge University Press, 274 p.

Golonka, J., and Kiessling, W., 2002, Phanerozoic time scale and definition of time slices, in Kiessling, W., Flügel, E., and Golonka, J., eds., Phanerozoic reef patterns: Society of Economic Paleontologists Special Publication, no. 72, p. $11-20$.

Gordadze, G.N., and Tikhomirov, V.I., 2006, Typification of oils in the Timan-Pechora Province according to the composition of hydrocarbon biomarkers (steranes and terpanes): Geochemistry International, v. 44, no. 3, p. 296-307.
Gradstein, F.M., Ogg, J.G., and Smith, A.G., Agterberg, F.P., Bleeker, W., Cooper, R.A., Davydov, V., Gibbard, P., Hinnov, L.A., House, M.R., Lourens, L., Luterbacher, H.P., McArthur, J., Melchin, M.J., Robb, L.J., Shergold, J., Villeneuve, M., Wardlaw, B.R., Ali, J., Brinkhuis, H., Hilgen, F.J., Hooker, J., Howarth, R.J., Knoll, A.H., Laskar, J., Monechi, S., Plumb, K.A., Powell, J., Raffi, I., Röhl, U., Sadler, P., Sanfilippo, A., Schmitz, B., Shackleton, N.J., Shields, G.A., Strauss, H., Van Dam, J., van Kolfschoten, T., Veizer, J., and Wilson, D., 2004, A geologic time scale, 2004: Cambridge, Cambridge University Press, 589 p.

Hardenbol, J., Thierry, J., Farley, M.B., Jacquin, T., de Graciansky, P.C., and Vail, P.R., 1998, Mesozoic and Cenozoic sequence chronostratigraphic framework for European basins, in de Graciansky, P.C., Hardenbol, J., Jacquin, T., and Vail, P.R., eds., Mesozoic and Cenozoic sequence stratigraphy of European basins: Society for Sedimentary Geology Special Publication, no. 60, p. 3-13.

IHS Energy Group, 2007 [includes data current through October 2007], International exploration and production database: Englewood, Colo., IHS Energy Group [database available from IHS Energy Group, 15 Inverness Way East, D205, Englewood, CO 80112, U.S.A].

Ismail-Zadeh, A.T., Kostyuchenko, S.L., and Naimark, B.M., 1997, The Timan-Pechora Basin (northeastern European Russia)-Tectonic subsidence analysis and a model of formation mechanism: Tectonophysics, v. 293, no. 1, p. 205-218.

Kaufman, J., and Jameson, J., 2002, Sequence stratigraphy, facies, and reservoir quality of lower Devonian carbonates in Roman Trebsa field, Timan-Pechora Basin, CIS, in Zempolich, W.G., and Cook, H.E., eds., Paleozoic carbonates of the Commonwealth of Independent States (CIS) Subsurface reservoirs and outcrop analogs: Society for Sedimentary Geology Special Publication, no. 74, p. 43-68.

Kouznetsov, N.B., Soboleva, A.A., and Udoratina, O.V., 2005, Architecture of neo-Proterozoic basement of northeastern European margin (Timan-Pechora Basin and northern part of central Urals Uplifts) as a result of the Arctida-Baltica collision: Geophysical Research Abstracts, European Geosciences Union, v. 7, no. 00884, 5 p.

Law, B.E., Bogatsky, V.I., Danileksky, S., and Galkina, L., 1996, Basin-centered gas accumulation in the TimanPechora Basin, Russia [abs.]: American Association of Petroleum Geologists Annual Convention Program, v. 5, p. A81.

Law, B.E., 2002, Basin-centered gas systems: American Association of Petroleum Geologists Bulletin, v. 86, no. 11, p. 1891-1919. 
Lindquist, S.J., 1999, The Timan-Pechora Basin Province of northwest Arctic Russia-Domanik-Paleozoic Total Petroleum System: U.S. Geological Survey Open-File Report 99-50-G, 40 p.

Lodzhevskaya, M.I., and Smolenchuk, T.N., 1998, Fluid dynamic aspects of oil migration and accumulation in the northeast of the Timan-Pechora Basin: Petroleum Geoscience, v. 4, p. 111-120.

Malyshev, N.A., Udin, V.V., and Schamel, S., 1991, Structural style and evolution of the Pechora Basin, USSR [abs]: American Association of Petroleum Geologists Bulletin, v. 75 , no. 8 , p. 1,416 .

Meyerhoff, A.A., 1980, Petroleum basins of the Soviet Arctic: Geological Magazine, v. 117, no. 2, p. 101-210.

O'Leary, N., White, N., Tull, S., Bashilov, V., Kuprin, V., Natapov, L., and MacDonald, D., 2004, Evolution of the Timan-Pechora and South Barents Sea basin: Geological Magazine, v. 141, no. 2, p. 141-160.

Otto, S.C., and Bailey, R.J., 1995, Tectonic evolution of the northern Ural orogen: Journal of the Geological Society of London, v. 152, p. 903-906.

Pairazain, V.V., 1993, Petroleum geochemistry of the TimanoPechora basin: First Break, v. 11, no. 7, p. 279-286.

Pollastro, R.M., Cook, T.A., Roberts, L.N.R., Schenk, C.J., Lewan, M.J., Anna, L.O., Gaswirth, S.B., Lillis, P.G., Klett, T.R., and Charpentier, R.R., 2008, Assessment of undiscovered oil resources in the Devonian-Mississippian Bakken Formation, Williston Basin Province, Montana and North Dakota: U.S. Geological Survey Fact Sheet 2008-3021, 2p.
Requejo, A.G., Sassen, R., Kennicutt, M.C., Kvedchuk, I., McDonald, T., Dennoux, G., Comet, P., and Brooks, J.M., 1995, Geochemistry of oils from the northern TimanPechora Basin, Russia: Organic Geochemistry, v. 23, no. 3, p. 205-222.

Sagers, M.J., 1994, Observations on oil and gas production in the Timan-Pechora Basin: International Geology Review, v. 36, p. 33-41.

Stephenson, R.A., Yegorova, T., Brunet, M.F., Stovba, S., Wilson, M., Starostenko, V., Saintot, A., and Kusznir, N., 2006, Late Paleozoic intra- and pericratonic basins on the East European craton and its margins: Geological Society of London Memoirs, v. 32, p. 463-479.

Ulmishek, G.F., 1982, Petroleum geology and resource assessment of the Timan-Pechora Basin, USSR, and the adjacent Barents-northern Kara Shelf: Argonne, Ill., Argonne National Laboratory, Energy and Environmental Systems Division Report ANL/EES-TM-199, 197 p.

Ulmishek, G.F., 2000, Timan-Pechora Basin-Geologic Province 1008, in U.S. Geological Survey World Energy Assessment Team, U.S. Geological Survey World Petroleum Assessment 2000-Description and results: U.S. Geological Survey Digital Data Series DDS-60, four CD-ROM set, disk 2.

Ulmishek, G.F., and Klemme, H.D., 1990, Depositional controls, distribution, and effectiveness of world's petroleum source rocks: U.S. Geological Survey Bulletin B-1931, $59 \mathrm{p}$.

Zhemchugova, V.A., and Schamel, S., 1994, Carboniferouslower Permian carbonate reservoirs of the Timan-Pechora Basin: International Geology Review, v. 36, p. 15-23. 


\section{Appendixes}

Appendixes are available online only, and may be accessed at https://doi.org/10.3133/pp1824N.

Appendix 1. Input Data for the Northwest Izhma Depression Assessment Unit

Appendix 2. Basin Evolution Chart for the Main Basin Platform Assessment Unit

Appendix 3. Input Data for the Main Basin Platform Assessment Unit

Appendix 4. Basin Evolution Chart for the Foredeep Basins Assessment Unit

Appendix 5. Input data for the Foredeep Basins Assessment Unit

Appendix 6. Detailed Assessment Results for the Main Basin Platform Assessment Unit

Appendix 7. Detailed Assessment Results for the Foredeep Basins Assessment Unit 
